\title{
An overview of the knapped stone economy at the Tărtăria site (Transylvanian Basin, Romania)
}

\author{
Otis Crandell \\ Department of Anthropology. Universidade Federal da Paraná. Curitiba, Paraná, Brazil. \\ Email: otis.crandell@gmail.com
}

\begin{abstract}
:
This study focused on sourcing the lithic artefacts from the Tărtăria site in the Transylvanian Basin. The objective was to establish a model of the procurement patterns of the population at the settlement. This site is located along the middle region of the Mures River and has several habitation levels belonging to the Vinča A, Vinča B, Vinča-Turdaș (or Vinča C), Petrești and Coțofeni cultures (Middle Neolithic to Chalcolithic). Most of the results of this study are based on analysis of the artefacts from Iuliu Paul's excavation in 1989. This knapped artefacts from the Tărtăria site were categorised by tool type, signs of usage and retouch, and probably geographic origin. The sources of the artefact materials were predicted based on macroscopic and petrographic analyses (polarized light optical microscopy).

The lithics appear to be made from the same types of materials found at other contemporary sites in the area. As with other sites, the most common imported material is obsidian, followed by Miorcani type Moldavian flint. Balkan flints represent only a small part of the assemblage. Of the local material, the vast majority is chert, likely local Trascău Mts. chert, which represents over half of the pieces in the assemblage. Although the site is closer to sources of jasper in the Metaliferi Mts. than some other Neotlihic and Chalcolithic sites down river, very few of the artefacts were made from jasper. (This may be due to an economic connection with nearby and contemporary, quarrying activity at the Răcătău-Piatra Tomii site.)

Obsidian is used almost exclusively for blades and flakes. The same is true for Miorcani Moldavian flint, although scrapers were not uncommon. Cores and scrapers are more common among local material than among imported material. The percentages of each artefact type seem to remain relatively similar for each culture (in other words, with the progress of time). This shows that people were still using the same general types of tools.

The percentages of the different materials varies over time though. During the Vinča A and Vinča B phrases, local materials represent approximately $30 \%$ of the assemblage and imported materials represent c. 70\%. After the Vinča B phase (in other words, entering into the Chalcolithic), the emphasis switches to local sources (representing c. 87\%) while imported drop to about $13 \%$.

Two important observations can be made from this study. Firstly, with the possible exception of Balkan flint, the imported materials came from outside of the territories of the cultures at this site. This indicates that areas of similar artistic style (the main characteristic used to define culture areas) do not in fact match areas of economic interaction. This further supports the need for a redefining of cultures and cultural territories. Secondly, although the inhabitants during the Late Neolithic and Chalcolithic used imported materials (especially obsidian), local materials became more and more predominant
\end{abstract}

Published by the School of History, Classics and Archaeology, University of Edinburgh ISSN: 2055-0472. URL: http://journals.ed.ac.uk/lithicstudies/

This work is licensed under a Creative Commons Attribution 2.5 UK: Scotland License. 
over time, possibly due to the introduction and continually increasing value of copper or increased self-sufficiency. The fact that this shift in material usage occurs most drastically during the transition to the Chalcolithic supports this idea.

Keywords: lithic artefacts; Neolithic; Chalcolithic; provenance; Carpathian Basin

\section{Introduction}

\subsection{Archaeological background: The Tărtăria - Gura Luncii site}

The prehistoric site of Tărtăria is located along the Mureș River near the town of Tărtăria (Săliștea commune) (Figures 1, 2, 3, and 4). More precisely, the site is located near the Tărtăria railway stop on the first terrace of the Mures,, at the location called "Gura Luncii". This site is considered an important Neolithic settlement with several habitation levels belonging to the Petrești and Vinča-Turdaș cultures. The site was first discovered by Orosz Endre in 1906 who noted a large Neolithic settlement analogous to that at Turdaș. He also noted the presence of obsidian (Orosz 1908). The first excavations at the site were in 1942 and 1943, led by Kurt Horedt (Horedt 1949; Radu 1967). Further excavations were conducted in 1961 by Nicolae Vlassa (Vlassa 1976) and in 1989 by Iuliu Paul along with Ioan Alexandru Aldea and Horea Ciugudean (Paul 2011). (See Figure 5)

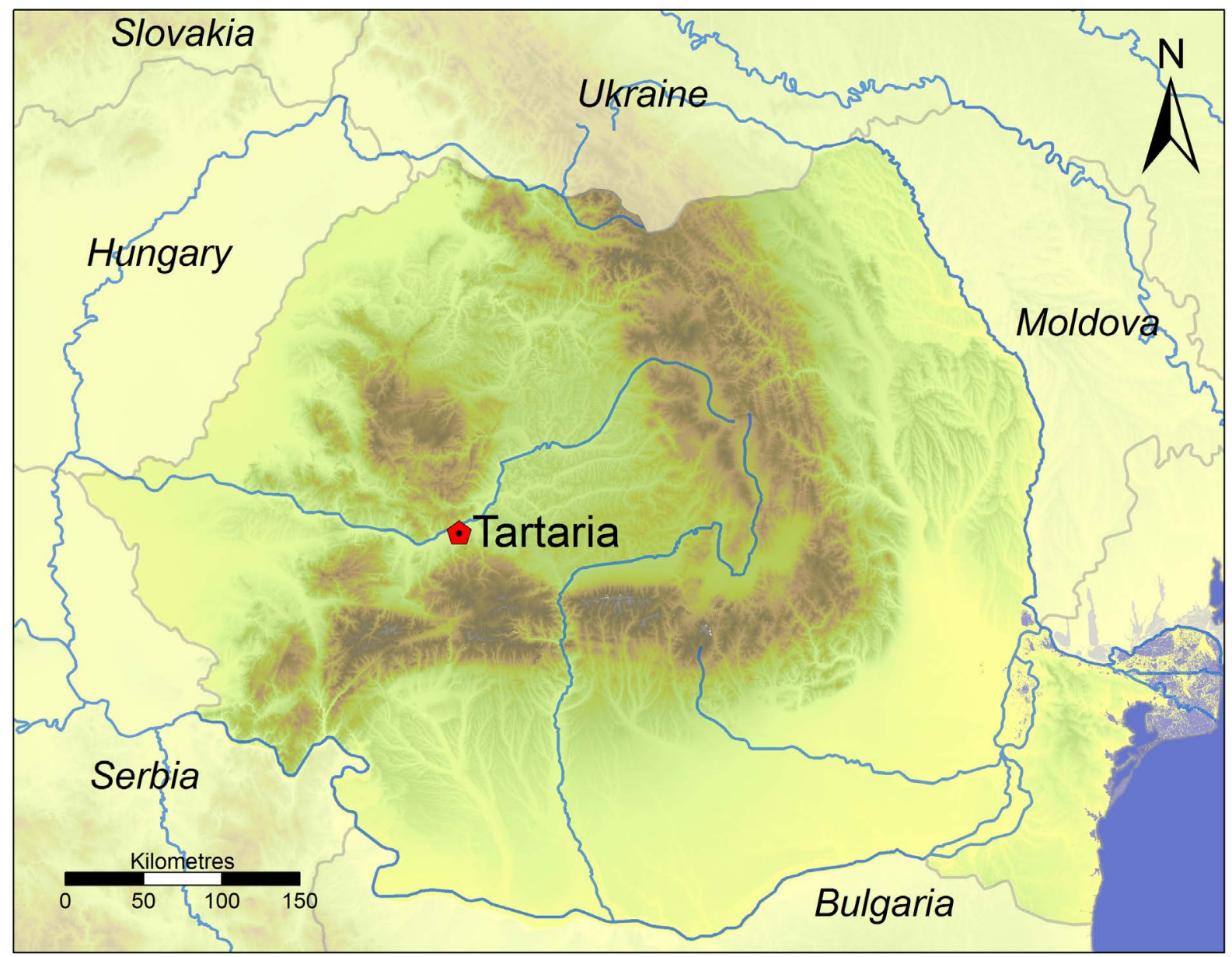

Figure 1. Map of Carpathians which shows the location of the Tărtăria site. 


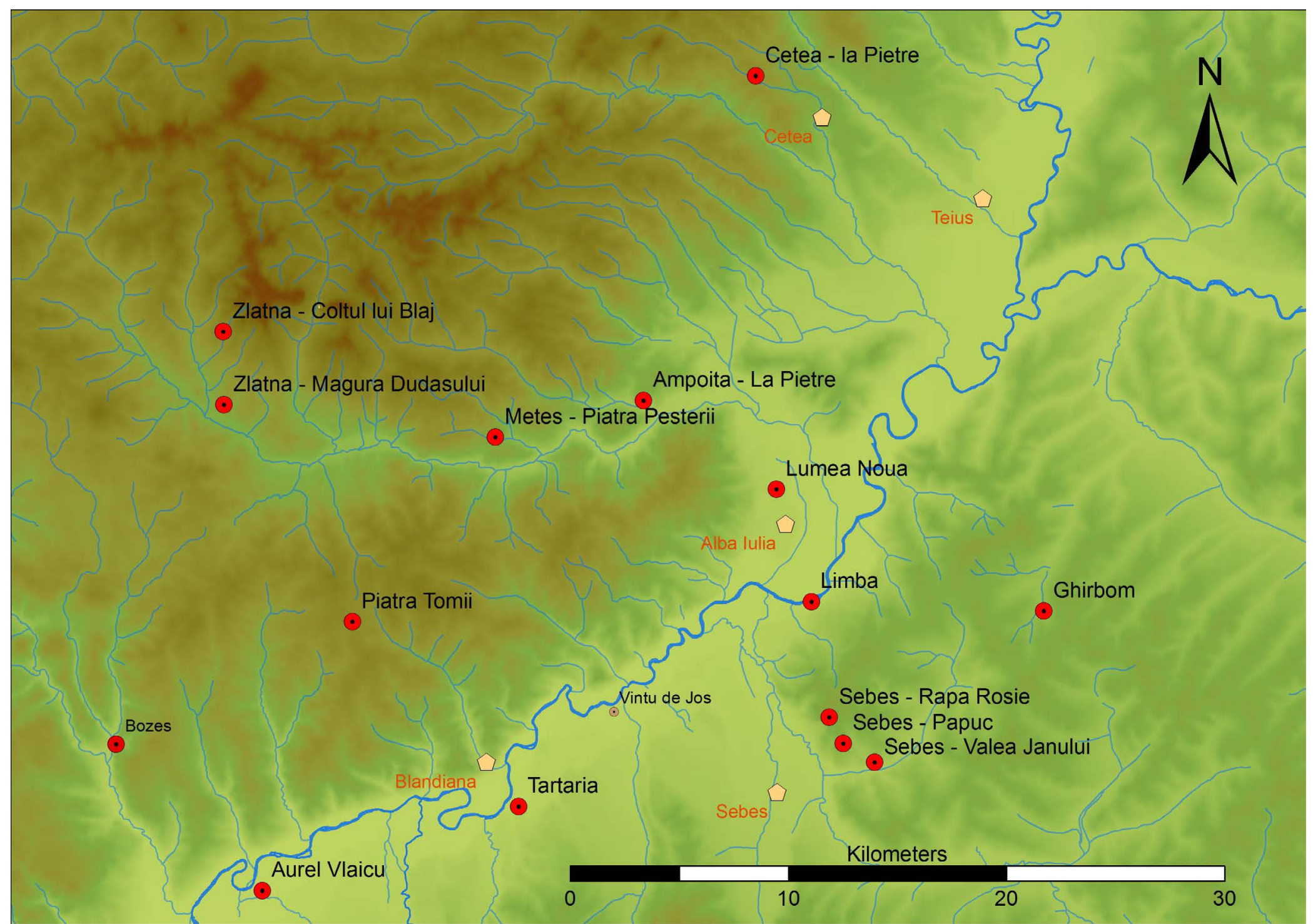

Figure 2. Map showing relatively contemporary sites from the Mureș Valley (marked with red circles). 


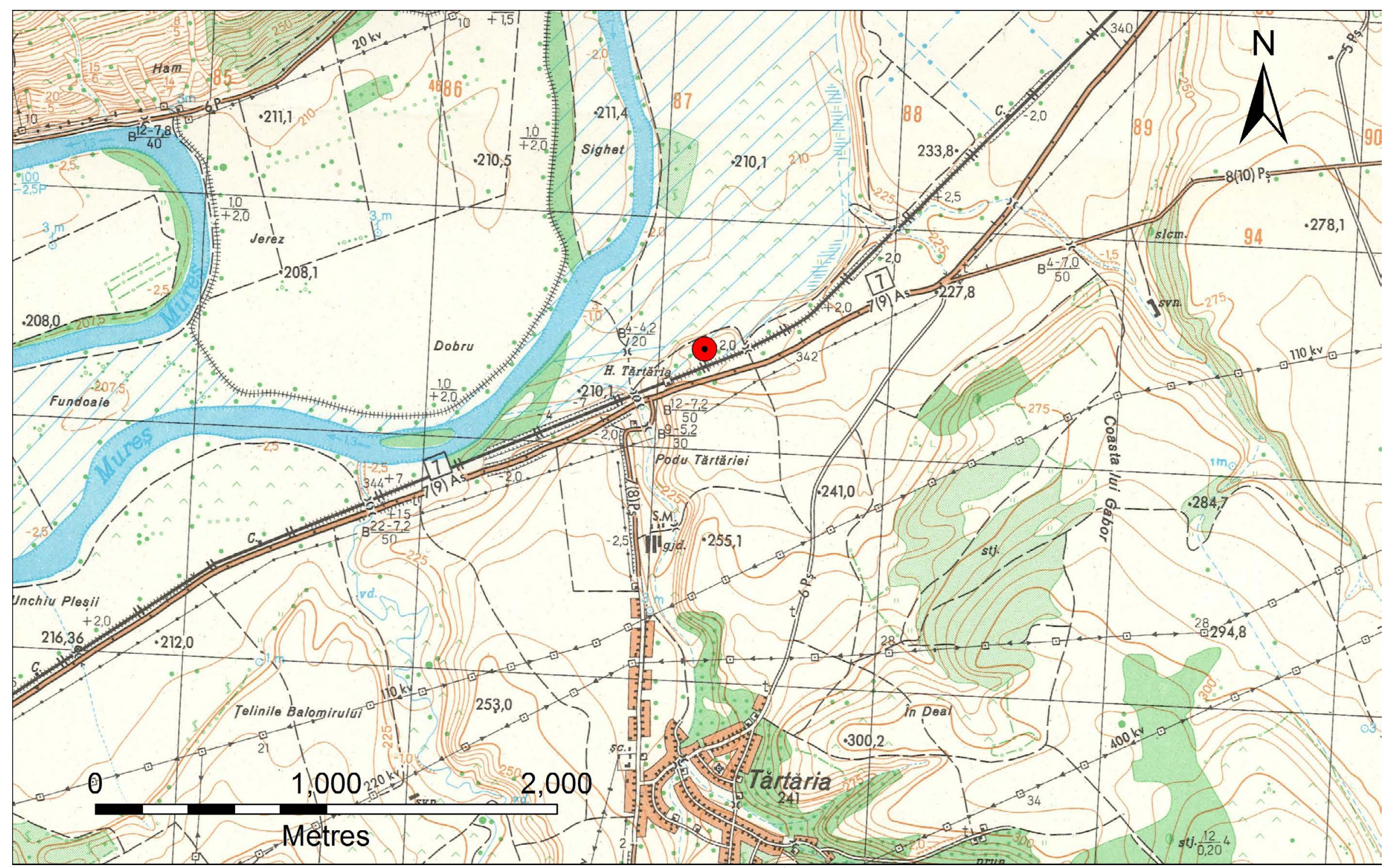

Figure 3. Area surrounding the Tărtăria site. From Romanian Topographic Map L-34-083-B-b, $2^{\text {nd }}$ Edition, 1:25,000 scale series. The red circle indicates the site. 


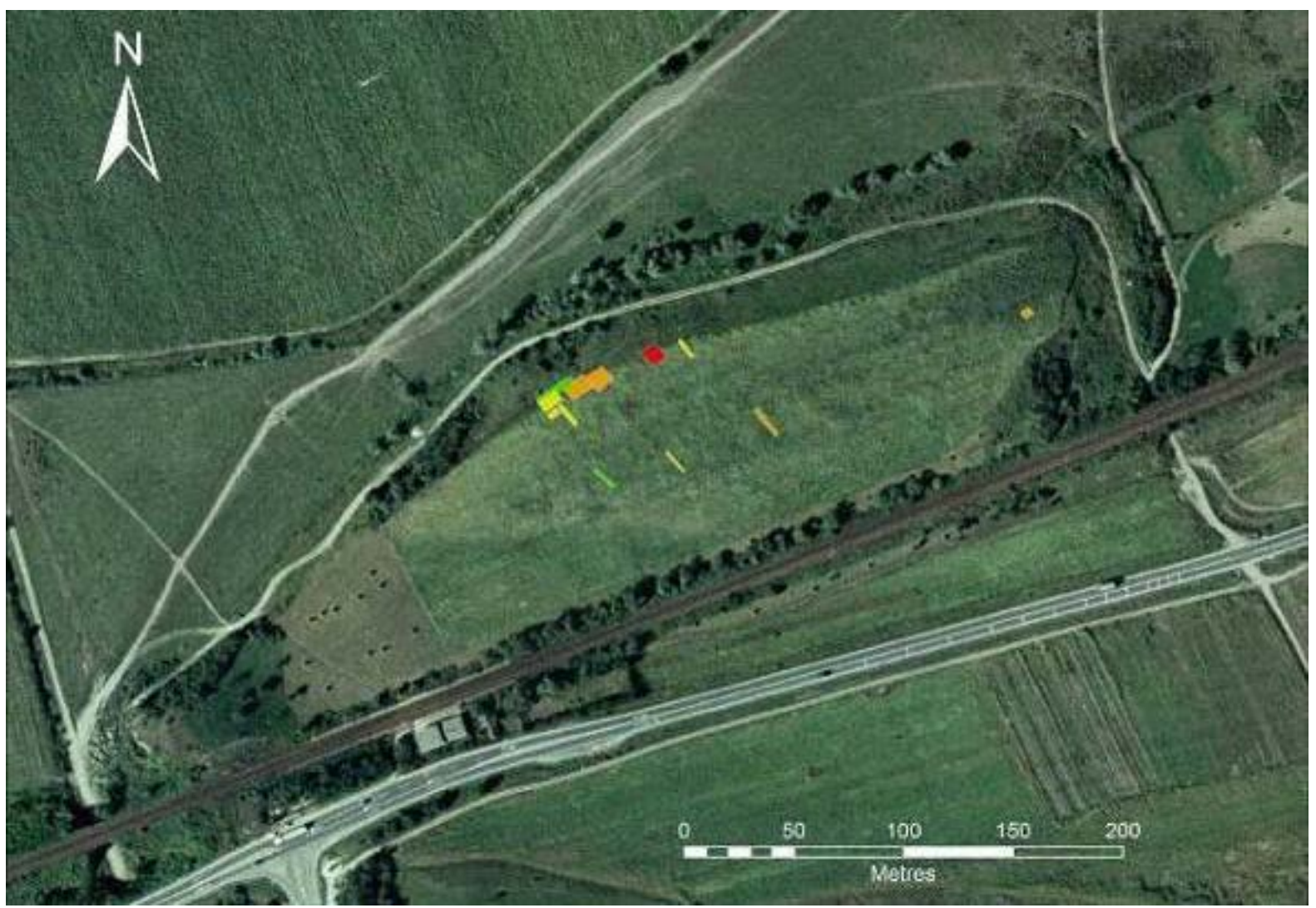

Figure 4. Tărtăria archaeological site with its excavated sectors indicated (coloured rectangles). The excavation trenches are labelled in Figure 5. Aerial photo from the ANCPI orthophoto dataset; site data based on unpublished field survey by Iuliu Paul; partial site data was published by Paul (2011: 51).

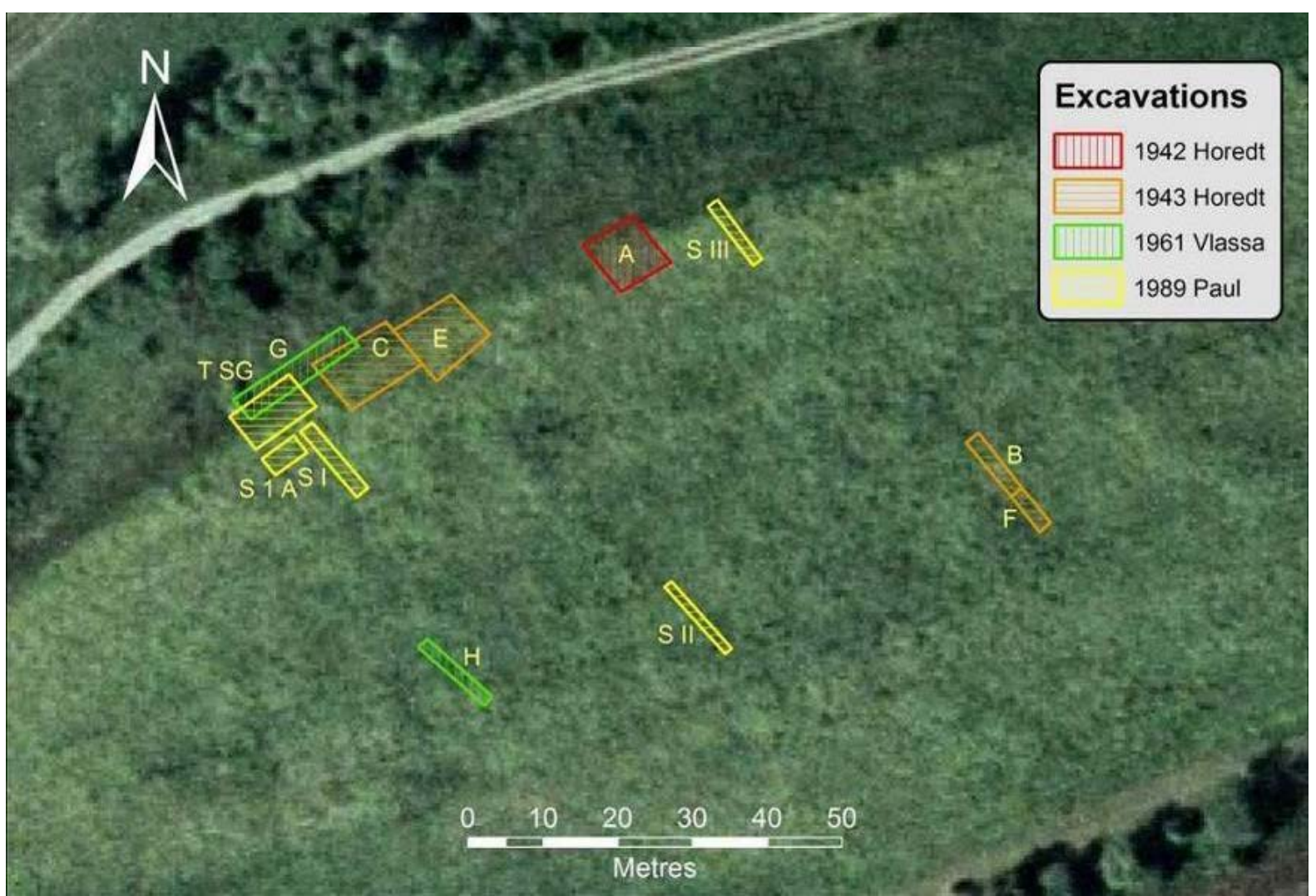

Figure 5. Excavations trenches at Tărtăria conducted between 1942 and 1989. Aerial photo from the ANCPI orthophoto dataset; site data from Paul (2011: 51). 
The lower level, belonging to the Vinča-Turdaș culture is characterized by pit house type dwellings. Here researchers also discovered a sacred pit, the contents of which contained the three famous clay tablets with graphic symbols, associated with idols and Spondylus shell bracelets. The Petrești level is characterized by surface houses with floors made from river stones. The Neolithic dwelling is followed by an early Coțofeni layer, which however has been largely destroyed due to agricultural work. In the layer disturbed by ploughing, in various parts of the settlement, researchers found ceramic shards belonging to the Early Bronze Age, the Wietenberg culture, middle Hallstatt culture (locally referred to as the Basarabi culture) and the early feudal period $\left(11^{\text {th }}\right.$ to $12^{\text {th }}$ century C.E.). During surface field surveying in 1988, from the ploughed ground, researchers collected burnt human bones, a bent iron dagger sheath, two fragments of iron cheeks (part of the bit from a harnessed horse) and a pendant from a sword scabbard, representing the remains of a cremation grave from the $2^{\text {nd }}$ to $1^{\text {st }}$ century B.C.E. On the same occasion, from another location of the settlement researchers discovered an iron Hallstatt celt. (The preceding paragraph is based on a report by Vasile Moga and Horea Ciugudean (Moga \& Ciugudean 1995: 185-186)). The locations of the various excavation trenches are indicated in Figure .

Based on the lithics assemblage from Paul's excavations, the majority of artefacts at the site are from the Middle Neolithic to the Chalcolithic. There are lithic artefacts from the Vinča A, Vinča B, Vinča-Turdaș (or Vinča C), Petrești and Coțofeni cultures. As the Coțofeni remains are in the ploughed layer, it is hard to determine how long or how large their settlement was. Otherwise, the majority of artefacts came from the Vinča B $(30 \%)$, VinčaTurdaș (21\%) and Petrești (28\%) levels. The artefacts from the excavations of Horedt and Vlassa are housed by the National Museum of Transylvanian History in Cluj-Napoca. Those from Paul's excavation are housed at the "1 Decembrie 1918” University in Alba Iulia.

The same cultures were also present at Răcătău-Piatra Tomii across the river in the mountains. It is very likely the two sites are contemporary. The connection between these two sites is noted in more detail by Crandell and Popa (2015).

\subsection{Lithic resources}

The lithic materials found at the Tărtăria site are found also at other Neolithic and Chalcolithic sites in the Mureș Valley, those being primarily obsidian, flint, chert, jasper, fine grained siliceous sandstone, and low quality materials (for example, in this case, quartzite). The sources of local or medium range materials appear to be Trascău chert, Metalifieri jaspers, and Strei sandstone. (Quartzite is often available in rivers, including the Mureș). The high quality materials are the same as those found throughout the Transylvanian basin Carpathian obsidian, Miorcani type Moldavian flint, and Balkan flint. These materials are described in previous publications (Crandell 2008; 2009b; 2011; 2012a; 2012b; 2012c; 2013; 2014a; 2014b; in press; Crandell \& Mărcuţi in press; Crandell et al. 2013; Crandell \& Popa 2015; Crandell \& Vornicu 2015) so only a brief mention will be made here for the benefit of readers who have not read (or do not have access to) the previous publications. By identifying the sources of raw materials in region, it was possible to identify probable sources of the artefacts.

\subsubsection{Local materials}

There are several raw materials within a day or two of travel which are suitable for knapping. The following is a general overview of the main groups of materials available to the people at the settlement. (Figure 6) 


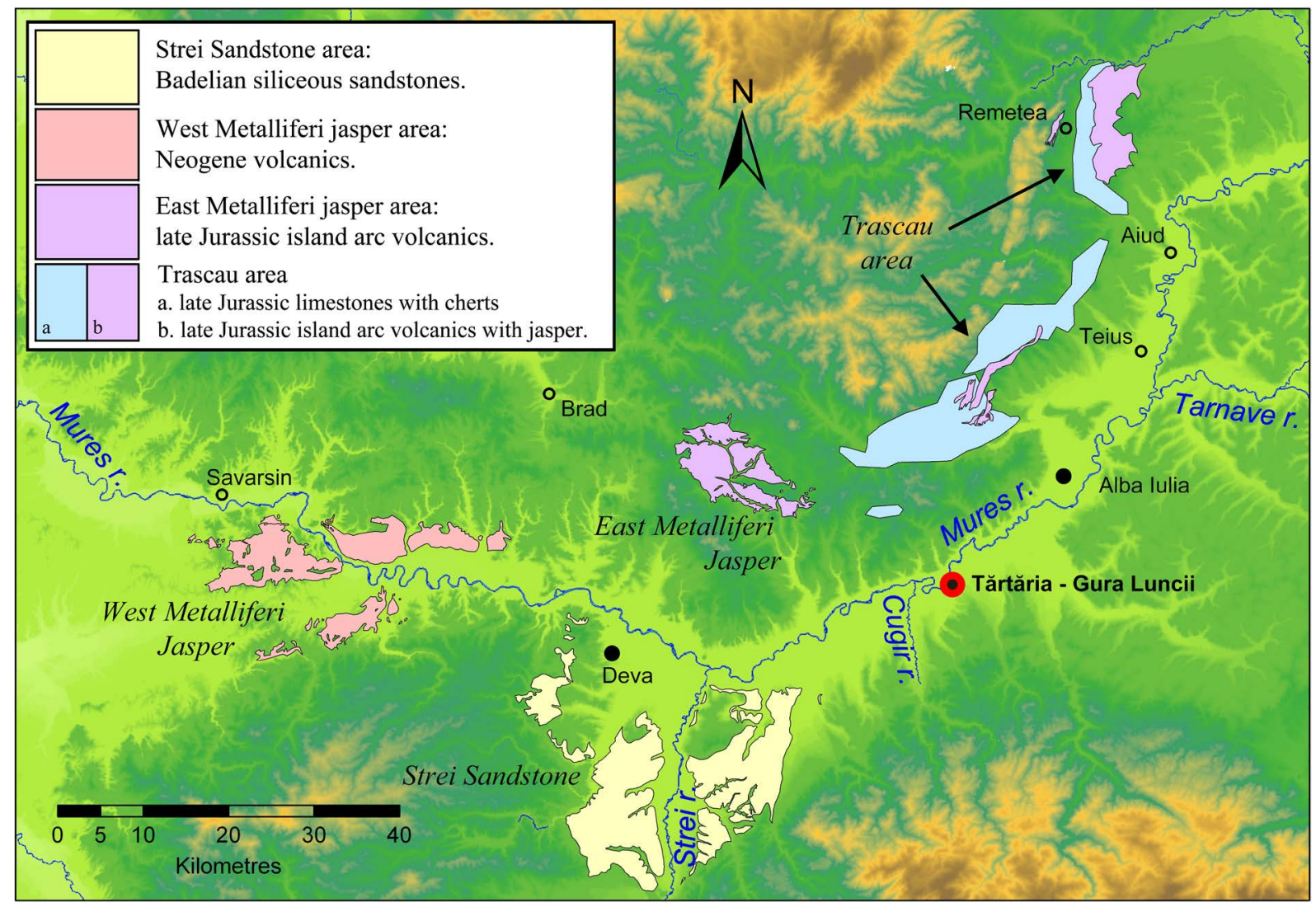

Figure 6. Map indicating the areas with outcrops of the main local materials. The red circle indicates the location of the site.

\section{Trascău chert}

Trascău chert occurs throughout the Trascău Mts. (particularly in the south) in or near to Late Jurassic (Tithonian) limestone outcrops from Blandiana in the south, to Cheile Turzii in the north (Lupu et al. 1966) (Figure 6). Material of similar appearance (or the same material) also occurs in the Late Jurassic limestone outcrops in the Metaliferi Mts., particularly in the eastern extreme. This material has been described in previous publications by the author (Crandell 2008; 2009b; 2012b; Crandell \& Popa 2015).

\section{Metalifeiri jaspers (two types)}

The Metaliferi Mts. contain two types of jasper, western- and eastern-type, respectively. Both are microcrystalline quartz varieties with high Fe-rich compounds content, macroscopically and microscopically very similar to each other.

West Metaliferi Jasper is from the western part of the Metaliferi Mts. and is geologically related to Miocene (Badenian-Sarmatian [Chronostratigraphic units are according to the Central Paratethys time-scale (Vass \& Balogh 1987).]) pyroclastic andesite formations, extending from Săvârşin to Bretea Mureșană (Gherasi et al. 1965; Lupu et al. 1991; Lupu et al. 1986) (Figure 6). In at least some places, jasper (Constantina 2008; Iancu \& Iancu 2009) is related to Late Cretaceous andesitic to dacitic pyroclastic rocks, so-called banatites (Giușcă et al. 1966).

The East Metaliferi jasper is associated with Late Jurassic island arc volcanics (IAV) (basalts, basaltic andesites, and andesites) extending from Balsa to Techereu (Borcoș et al. 1981; Gandrabura 1981; Ghiurcă 1997; 2000; Lupu et al. 1966; Lupu et al. 1991; Lupu et al. 1986; Nicolae \& Saccani 2003; Savu 1990) (Figure 6). The same formation containing jasper exists also in the Trascău Mts. (related to the Jurassic ophiolites (Nicolae \& Saccani 2003)). 
Although from different occurrences, jasper from the western and eastern part of the Metaliferi Mts. is hard to distinguish using macroscopic or microscopic methods. This material has been described in previous publications (for examples, see Constantina 2008; Crandell 2008; 2009b; Pop et al. 2004).

\section{Strei sandstone}

Siliceous sandstone (more or less calcareous) occurs as outcrops and river pebbles in the northern part of the Strei Valley, south of the town of Simeria in Hunedoara county (Figure 6) (Crandell 2008; 2009b; 2012a; 2012b). Within this formation, there are more siliceous levels. These rocks are of Badenian age (Gherasi et al. 1965).

\subsubsection{Imported high quality materials}

In the larger region, there are three main high quality materials. In particular, those materials are flint from the Moldavian Plateau, obsidian from the Western Carpathians, and flint from along the lower Danube within the Dobruja region. These materials are very good quality for making knapped stone tools. Research in the larger overall region indicates that these three materials were transported over long distances (for example, Biagi et al. 2007a; Biagi et al. 2007b; Comșa 1975; 1976; 1982; Crandell 2008; 2012a; 2012b; 2012c; 2013). (See the map in Figure 7 for the locations of the source areas.)

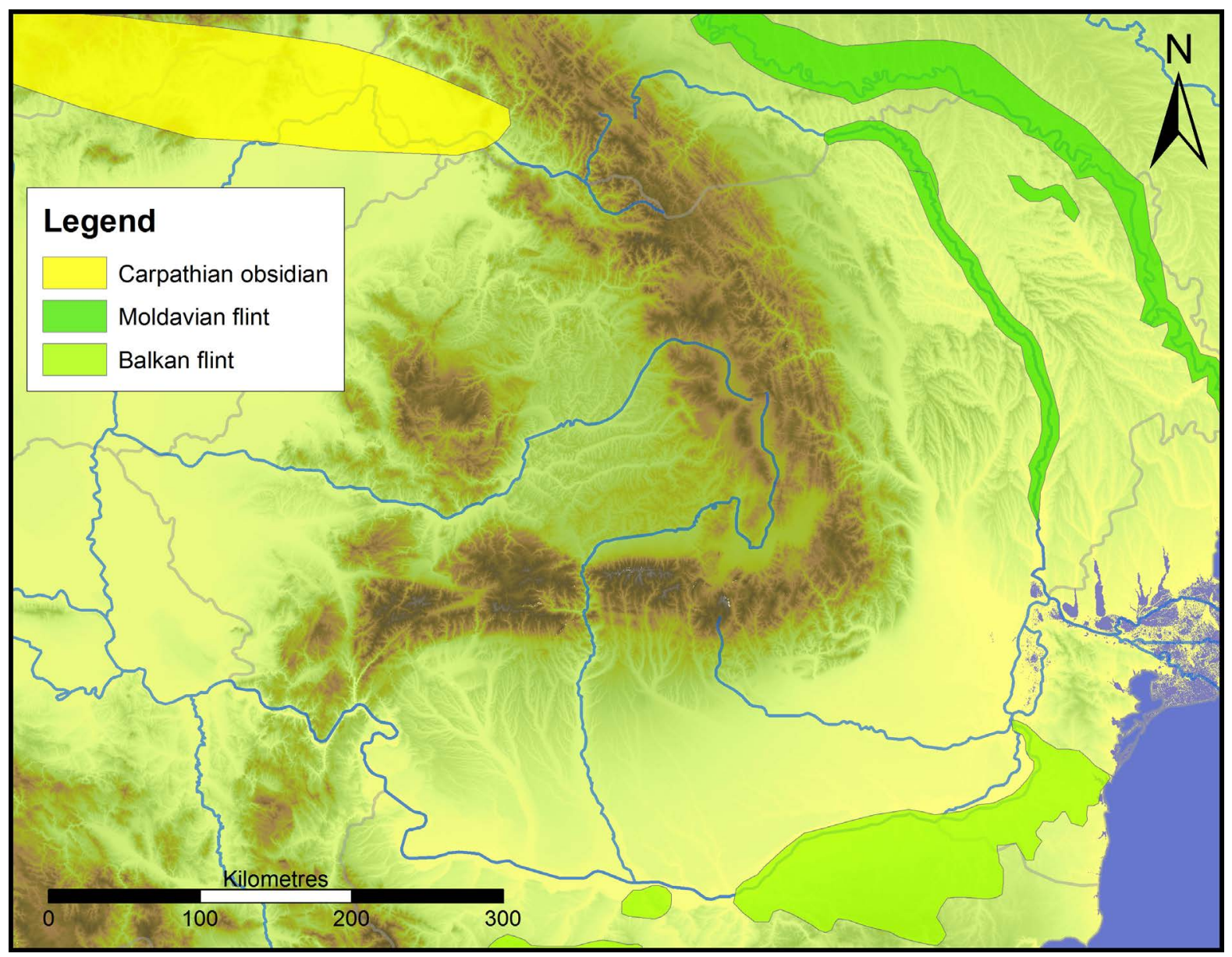

Figure 7. Map of high quality materials mentioned in this article. 


\section{Miorcani type Moldavian flint}

Miorcani type Moldavian flint consists of both chert (flint) nodules in Upper Cretaceous (Cenomanian) chalky marl cropping out along the Upper Prut and Dniester Rivers (Figure 7), and pebbles and cobbles in the alluvial sediments of the same rivers and the surface between them, as well as cobbles in the Badenian conglomerates cropping out near these rivers (Alba et al. 1960: 9-23; Chelărescu et al. 1961; Chirica et al. 1996; Ionesi \& Costea 1993; Macovei \& Atanasiu 1934: 179-181; Saulea et al. 1966; Simionescu 1897; Văscăuțanu 1923; 1925). Until recently, the material was mined near the town of Miorcani. It should be noted that there are various types of chert (or flint) in the Moldavian plateau. As only one type of Moldavian flint is discussed in this paper, it will sometimes be referred to as simply "Moldavian flint" or "flint from the Moldavian plateau" but in these instances it is still implied that the Miorcani type is meant. In archaeological literature, it is also referred to as 'Prut flint', 'Dniester flint', 'Moldavian flint' and 'Volhynian flint' (Barfield 2004; Biagi \& Voytek 2006; Boghian 2009; Połtowicz-Bobak 2005; Ryzhov et al. 2005; Sytnyk et al. 2007; Szakmány et al. 2011). Note that these other names are not always used exclusively for this material. A detailed description of this material has been made in previous publications (Crandell 2008; 2009b; 2012a; 2012b; 2012c; 2013; in press; Crandell \& Mărcuţi in press; Crandell et al. 2013; Crandell \& Vornicu 2015).

\section{Carpathian obsidian}

The two nearest obsidian sources areas are the Western Carpathian Mountains, mainly in Hungary and Slovakia (Biagi et al. 2007b; Rosania et al. 2008; Ryzhov et al. 2005) (Figure 7) as well as the Aegean and Anatolian region. Chemical analysis of artefacts can distinguish between various sources of obsidian (Biagi et al. 2007b; Biró 2006: 271; Kasztovszky \& Biró 2006: 303; Oddone et al. 1999; Rosania et al. 2008; Ryzhov et al. 2005), but macroscopically and microscopically it is very difficult. The Western Carpathian sources are much closer to the site. Studies from elsewhere in the Carpathian region indicated that all artefacts analysed came from Western Carpathian sources. (See for example, Biagi et al. 2007b; Constantinescu et al. 2002; Sălăgean et al. 1988: 73-86). This may be due to a limited number of geochemical studies of obsidian in this area but it seems that at least the majority (if not all) was imported from Western Carpathian sources. Still, all obsidian, regardless of where it came from, can be considered a long distance imported material. This material has previously been discussed in other publications by the author (Crandell 2008; 2012a; 2012b; 2013).

\section{Balkan flint}

In the Dobruja region of Romania and Bulgaria and along the lower part of the Danube River there are abundant sources of good quality flint, the so-called 'Balkan flint' (Biagi \& Starnini 2010; 2011; Jolkičev 2007; Nachev 2009). (See Figure 7 for a map indicating the source area.) Current research in Bulgaria indicates that several different materials from that region are referred to as 'Balkan flint' (Biagi \& Starnini 2010; Bonsall et al. 2010; Gurova 2008; Nachev 2009). One of these materials which comes from the Late Cretaceous chalk formations along the Danube and in Dobruja is a true flint. In Romania it is sometimes referred to as Murfatlar type flint but is also referred to as Dobruja flint and Moesian flint. (Brana 1967: 421-422; Chiriac 1957: 93, Table B; 1964: 336; 1981: 12-22; Chiriac et al. 1977; Ciocârdel 1953: 157; Ciocârdel \& Popovici 1954: 322; Ianovici et al. 1961: 47, Table 3; Ionesi 1988: 112; Macovei 1958: 368; Macovei \& Atanasiu 1934: 203-207; Mutihac \& Ionesi 1974: 99-101). A description of Balkan material can also be found in other papers by 
the author (for example, see Crandell 2008; 2012a; 2012c; 2013; in press; Crandell \& Mărcuţi in press; Crandell et al. 2013; Crandell \& Vornicu 2015)

\section{Methods}

Analyses of artefacts and lithic raw materials were used to determine geological sources of the artefacts. Although visual and petrographic analyses (as with most analyses) cannot always predict where a material came from, they can narrow down the possibilities. In the absence of known cultural influences, practical or functional information were used to decide on the most likely sources of artefacts. In other words, if there was no reason to think otherwise, the nearest possible source was assigned.

In this study, 308 of the knapped lithic artefacts found at the site were compared to rocks sampled from potential sources in the Transylvanian basin, Moldavia, Dobruja and adjacent areas. All of the artefacts were macroscopically analysed.

The macroscopic observations were followed by optical microscopy (OM) in plan polarised light, carried out at the Babeş-Bolyai University geology department on thin sections cut from 15 of the artefacts and on the thin sections of rock samples from the lithotheque. A Nikon Eclipse E200 Pol microscope was used and images were captured with a Nikon D3100 DSLR camera with a microscope ocular lens. Macroscopic and microscopic observations for each geological sample and artefact were stored in a database (Crandell 2005; 2006; 2009b).

Descriptions were based on an objective system, with a finite number of predefined terms. For details of the system used to describe the artefacts, see previous works by the author (in particular, Crandell 2005; 2006).

\section{Data results and interpretations}

Several artefact collections from Tărtăria were studied. These sets of artefacts were based on the researchers who have excavated at the site. The first collection was from Vlassa's excavations (housed at the National Museum of Transylvanian History in Cluj-Napoca), the next was from Horedt's excavations. The final and most intensively studied was from Paul's excavation.

\subsection{Artefacts from the excavations of Vlassa and Horedt}

The artefacts from Vlassa's excavations at Tărtăria seem to be incomplete. There are only a few knapped stone artefacts, probably due to the excavation methodology or the research objectives at the time. The lithic assemblage from Vlassa's excavation appear to consist of a few large artefacts made from medium quality, local chert - most likely coming from the Upper Jurassic limestone formations across the Mureș River.

The lithic assemblage from Horedt's excavations is much larger and has much more detailed labels regarding where they were found at the excavation. The types of material are also more diverse than those from Vlassa's excavation. Due to the limited time for analyses, it was not possible to study them in detail or to record how many of each material type were present. Instead, descriptions of the typical pieces were recorded and general observations were made regarding the material types present.

\subsection{Artefacts from the excavation of Paul}

The materials from Paul's excavations were studied in more detail. The observations below are based on these artefacts. From this assemblage, the knapped artefacts appear to be 
made from mostly of the same types of materials found at the Limba and Lumea Nouă sites, only in different proportions.

Overall, imported materials only represent a third of the artefacts (Table 1, Figures 9 and 10). As noted below, this varies over time. For a more accurate comparison of material ratios, it is necessary to compare the materials used by each culture at the sites. As with other sites in the area (for example, Limba and Lumea Nouă), the most common imported material is obsidian, followed by Miorcani type Moldavian flint. Balkan flint represents only a small part of the assemblage. Of the local material, the vast majority is chert. In fact, chert (likely local Trascău chert) itself represents over half of the pieces in the assemblage. Although the site is closer to sources of jasper in the Metaliferi Mts., very few of the artefacts were made from jasper.

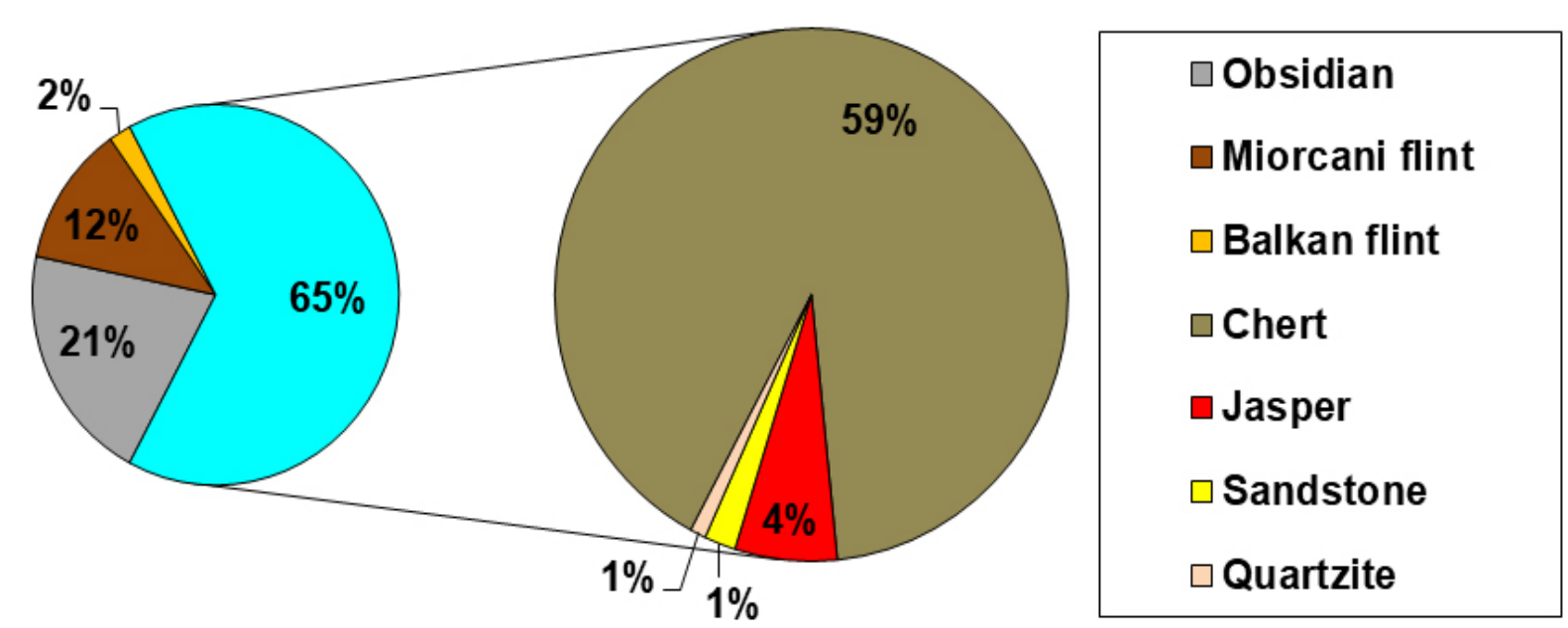

Figure 9. Proportions of artefacts provenances. (Percentages are rounded to the nearest whole number.)

As with other sites in the area, there is differential usage of materials for specific tools (Table 2). Obsidian is used almost exclusively for blades and flakes. There is a higher than average use of obsidian for blades and lower than average for scrapers and cores. An average number of Moldavian flint artefacts were blades and flakes but slightly higher number of scrapers. There was a slightly lower number of local material pieces in the form of blades (blades and flakes occur in higher percentage among imported material artefacts) but slightly higher number of scrapers and cores made from local materials than from imported materials. For examples of artefact and material types, see Figures 11 and 12. These data suggest that the local materials were processed more at the site, whereas imported materials were likely produced elsewhere and brought to the site ready-made. Again, the low proportion of obsidian scrapers is likely a technical preference.

It should be noted that in this study, "flakes" are a general category of artefact. Some may have been tools, but others may have been debitage. Only if it was clear that a piece had no intended use was it classified as debitage. If its specific use was known, then it was classified as a blade, scraper, burin or a core. The category of "core" includes depleted and unused cores, as well as core fragments and core caps. Similarly, blades fragments were considered blades since it is hard to determine at what point a blade would be discarded after being broke rather than being re-used. Side scrapers and end scrapers were totalled together. Some side scrapers and general flakes are hard to distinguish. Although general flakes may have been used as scrapers, artefacts were only categorised as a scraper if they appeared to have been retouched or pressure flaked to produce a scraping edge. 


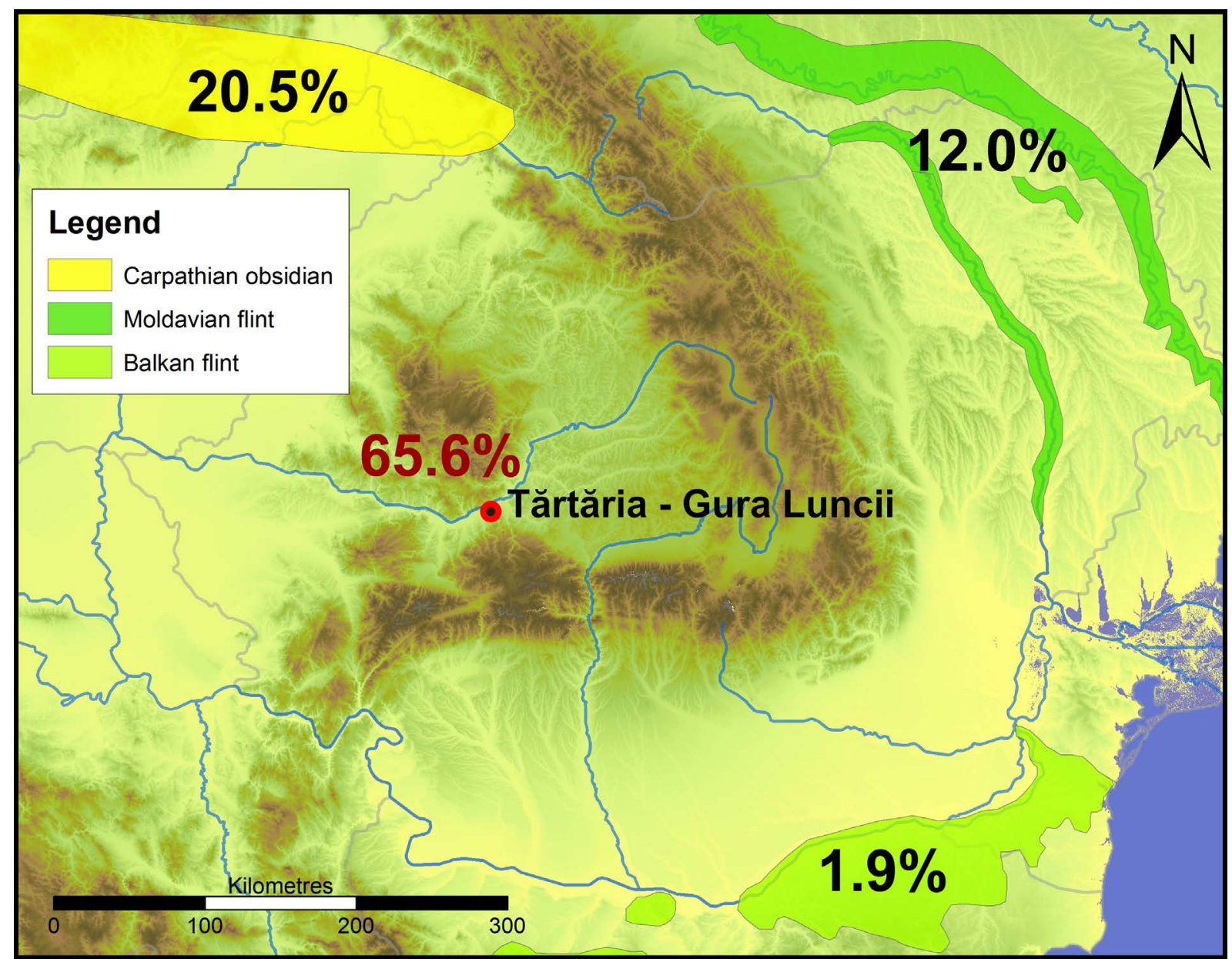

Figure 10. Provenances. Local materials (65.6\%) are collectively marked in dark red.

There appears to be an increased percentage of blades among artefacts made from imported materials (Table 3). As with other sites, blades and flakes represent the majority of artefacts, particularly among artefacts made from imported materials. They occur in higher percentage among imported material artefacts. Among local materials, cores and scrapers seem to be slightly more common. The percentages of each artefact type seem to remain relatively similar for each culture. The variations may be due to the small size of the assemblages when divided between cultures. This shows that people were still using the same general types of tools. This is important to note because it means that any change in the raw materials is due to a cultural cause not a need for particular raw materials. The potential cultural causes will be discussed in the conclusions section.

After the Vinča B phase, the emphasis on raw materials at Tărtăria switches to local sources (Tables 4 to 9), similar to Limba and Lumea Nouă (Crandell 2008; 2009a; 2012b) and coincides with the arrival of the Chalcolithic. Obsidian is more commonly used than Moldavian flint. Balkan flint was used less than Moldavian flint.

There are similar patterns of usage between obsidian and Moldavian flint (Tables 7 and 8). Obsidian is slightly more commonly used though. There are only a few Balkan flint artefacts in this assemblage so it is difficult to accurately compare its usage with that of obsidian and Moldavian flint. 
Table 1. Materials and sources for the chipped stone artefacts from Tărtăria.

\begin{tabular}{|c|c|c|c|c|c|}
\hline Category & Quantity & Percentage of assemblage & Specific materials & Quantity & Percentage of assemblage \\
\hline \multirow[t]{3}{*}{ Imported } & 106 & $34.4 \%$ & Moldavian flint & 37 & $12.0 \%$ \\
\hline & & & Balkan flint & 6 & $1.9 \%$ \\
\hline & & & Obsidian & 63 & $20.5 \%$ \\
\hline \multirow{3}{*}{ Local } & & & Jasper & 13 & $4.2 \%$ \\
\hline & & & Sandstone & 4 & $1.3 \%$ \\
\hline & & & Quartzite & 2 & $0.6 \%$ \\
\hline
\end{tabular}

Table 2. Raw materials used for different types of artefacts at the Tărtăria site.

\begin{tabular}{|c|c|c|c|c|c|c|c|c|c|c|c|c|}
\hline \multirow[t]{2}{*}{ Artefact types } & \multicolumn{2}{|c|}{ ALL } & \multicolumn{2}{|c|}{ Imported } & \multicolumn{2}{|c|}{ Obsidian } & \multicolumn{2}{|c|}{ Moldavian flint } & \multicolumn{2}{|c|}{ Balkan flint } & \multicolumn{2}{|c|}{ Local } \\
\hline & $\mathbf{n}$ & $\%$ & $n$ & $\%$ & $n$ & $\%$ & $n$ & $\%$ & $n$ & $\%$ & $n$ & $\%$ \\
\hline Debitage & 2 & $0.6 \%$ & & & & & & & & & 2 & $1.0 \%$ \\
\hline Blades & 120 & $39.0 \%$ & 48 & $45.3 \%$ & 30 & $47.6 \%$ & 15 & $40.5 \%$ & 3 & $50.0 \%$ & 72 & $35.6 \%$ \\
\hline Cores & 23 & $7.5 \%$ & 2 & $1.9 \%$ & 2 & $3.2 \%$ & 0 & $0.0 \%$ & 0 & $0.0 \%$ & 21 & $10.4 \%$ \\
\hline Flakes & 127 & $41.2 \%$ & 48 & $45.3 \%$ & 28 & $44.4 \%$ & 17 & $45.9 \%$ & 3 & $50.0 \%$ & 79 & $39.1 \%$ \\
\hline Perforator & 1 & $0.3 \%$ & 1 & $0.9 \%$ & 1 & $1.6 \%$ & & & & & 0 & $0.0 \%$ \\
\hline Total & 308 & & $\begin{array}{c}106 \\
34.4 \% \\
\end{array}$ & & $\begin{array}{c}63 \\
20.5 \% \\
\end{array}$ & & $\begin{array}{c}\mathbf{3 7} \\
12.0 \% \\
\end{array}$ & & $\begin{array}{c}\mathbf{6} \\
1.9 \% \\
\end{array}$ & & $\begin{array}{c}\mathbf{2 0 2} \\
65.6 \%\end{array}$ & \\
\hline
\end{tabular}



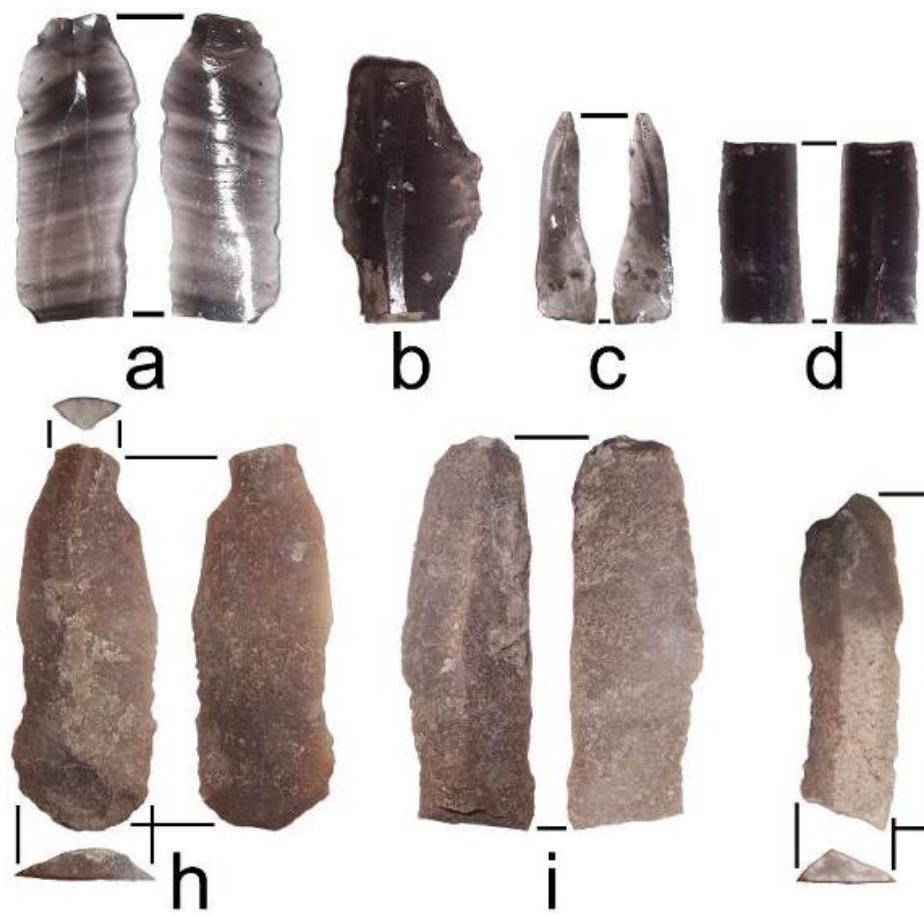

b

C
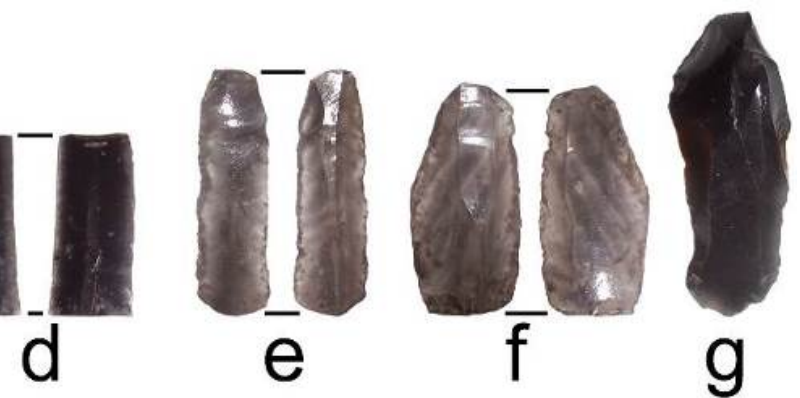

e
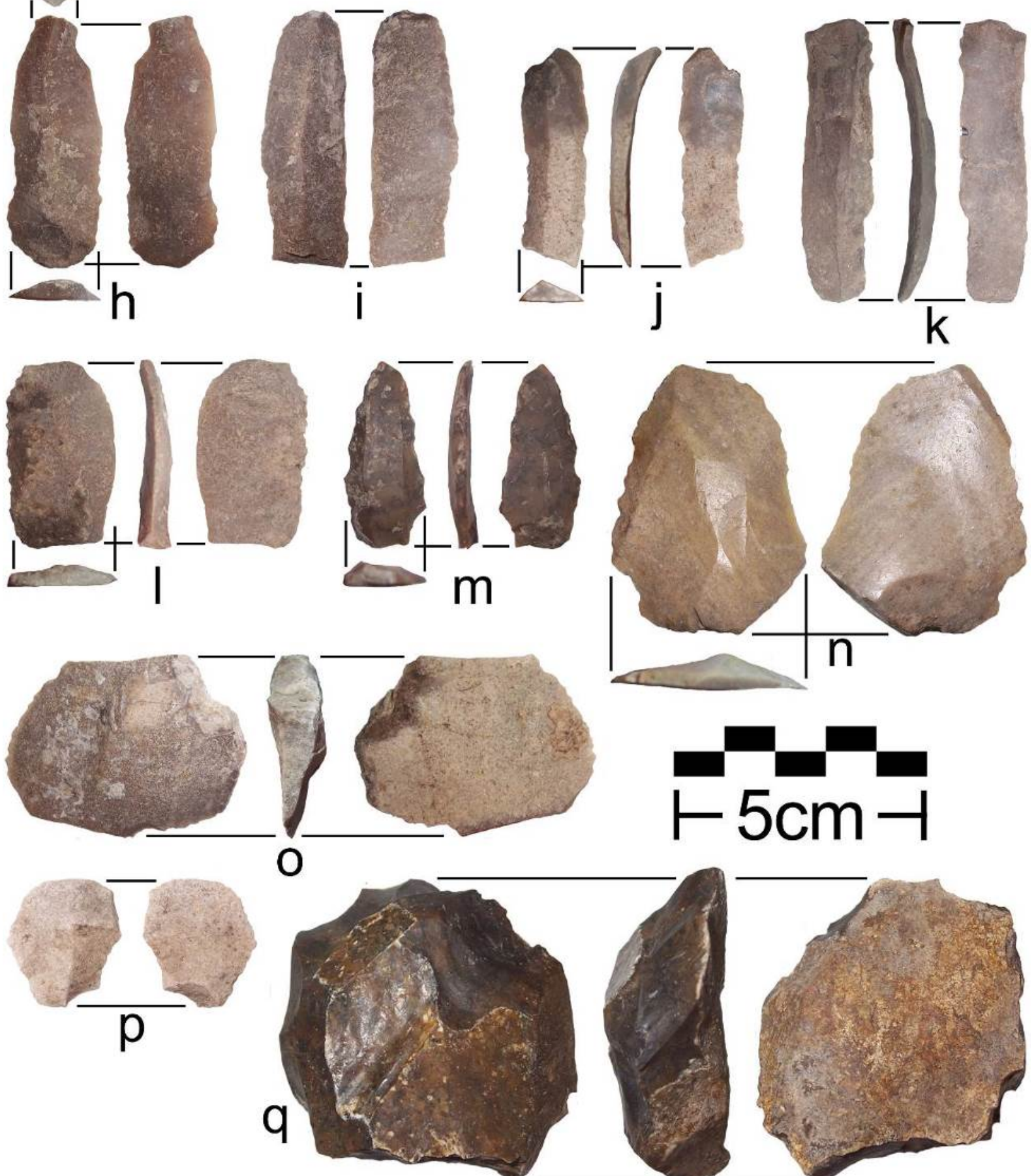

Figure 11. Examples of lithic artefacts from the Tărtăria site. a) to g) obsidian blades; h) to k) chert blades; l) chert blade or side scraper; $m$ ) jasper blade or side scraper; n) chert side scraper; o) \& p) flakes (possibly used as scraper or blades); q) jasper chopper (possibly a scraper). 

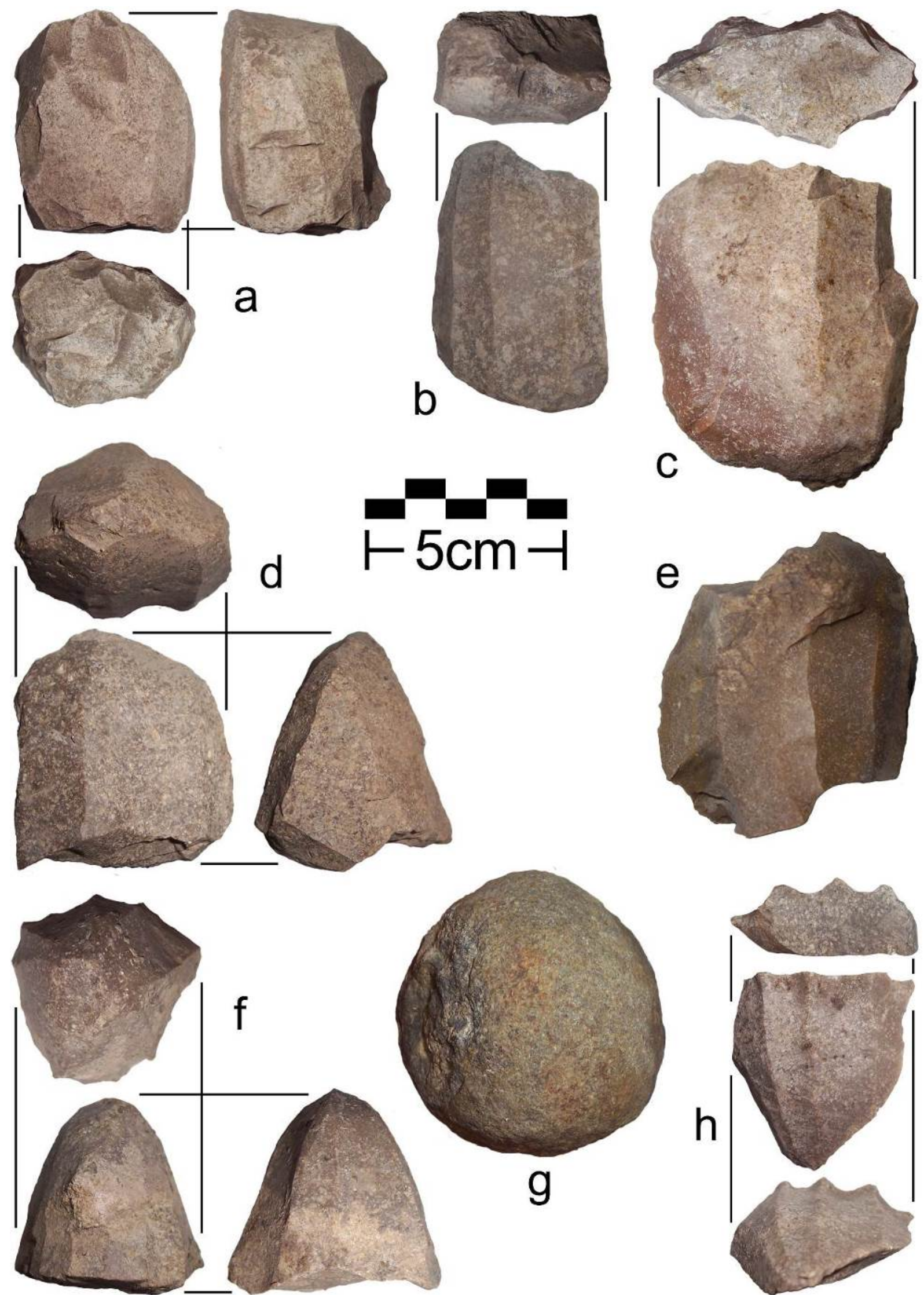

Figure 12. Examples of lithic artefacts from the Tărtăria site. a) to f) \& h) cores; g) a pounding or grinding stone. 
Table 3. Tools by culture group at Tărtăria site. The percentages highlighted in orange indicate the highest proportion artefact type for each culture phase. Those highlighted in blue are the second highest.

\begin{tabular}{|c|c|c|c|c|c|c|c|c|c|c|c|c|c|}
\hline Culture & Debitage & $\%$ & Blades & $\%$ & Scrapers & $\%$ & Cores & $\%$ & Flakes & $\%$ & Perforator & $\%$ & TotalS \\
\hline Vinča A & 0 & & 13 & $48.1 \%$ & 1 & $3.7 \%$ & 1 & $3.7 \%$ & 12 & $44.4 \%$ & 0 & & 27 \\
\hline Vinča B & 1 & $1.1 \%$ & 33 & $37.5 \%$ & 8 & $9.1 \%$ & 3 & $3.4 \%$ & 42 & $47.7 \%$ & 1 & $1.1 \%$ & 88 \\
\hline Vinča B-C & 0 & & 1 & $8.3 \%$ & 3 & $25.0 \%$ & 3 & $25.0 \%$ & 5 & $41.7 \%$ & 0 & & 12 \\
\hline Vinča C / Turdaș & 0 & & 18 & $51.4 \%$ & 4 & $11.4 \%$ & 1 & $2.9 \%$ & 12 & $34.3 \%$ & 0 & & 35 \\
\hline Turdaș-Petrești & 0 & & 12 & $24.0 \%$ & 5 & $10.0 \%$ & 6 & $12.0 \%$ & 27 & $54.0 \%$ & 0 & & 50 \\
\hline Petrești & 1 & $1.4 \%$ & 33 & $44.6 \%$ & 12 & $16.2 \%$ & 8 & $10.8 \%$ & 20 & $27.0 \%$ & 0 & & 74 \\
\hline Petrești-Coțofeni & 0 & & 10 & $45.5 \%$ & 2 & $9.1 \%$ & 1 & $4.5 \%$ & 9 & $40.9 \%$ & 0 & & 22 \\
\hline All cultures & 2 & $0.6 \%$ & 120 & $39.0 \%$ & 35 & $11.4 \%$ & 23 & $7.5 \%$ & 127 & $41.2 \%$ & 1 & $0.3 \%$ & 308 \\
\hline
\end{tabular}

Table 4. Raw materials by culture group at Tărtăria. The percentages highlighted in green represent the most common material used during the Neolithic phases of the site. Those highlighted in pink represent the most common material used during the Chalcolithic phases.

\begin{tabular}{|c|c|c|c|c|c|c|c|c|}
\hline Culture & Moldavian flint & Balkan flint & Obsidian & Chert & Jasper & Sandstone & Quartzite & Totals \\
\hline \multirow[t]{2}{*}{ Vinča A } & 7 & 0 & 10 & 8 & 1 & 1 & 0 & 27 \\
\hline & $25.9 \%$ & & $37.0 \%$ & $29.6 \%$ & $3.7 \%$ & $3.7 \%$ & & \\
\hline \multirow[t]{2}{*}{ Vinča B } & 23 & 6 & 34 & 18 & 7 & 0 & 0 & 88 \\
\hline & $26.1 \%$ & $6.8 \%$ & $38.6 \%$ & $20.5 \%$ & $8.0 \%$ & & & \\
\hline \multirow[t]{2}{*}{ Vinča B-C } & 1 & 0 & 2 & 9 & 0 & 0 & 0 & 12 \\
\hline & $8.3 \%$ & & $16.7 \%$ & $75.0 \%$ & & & & \\
\hline \multirow[t]{2}{*}{ Vinča C / Turdaș } & 4 & 0 & 6 & 25 & 0 & 0 & 0 & 35 \\
\hline & $11.4 \%$ & & $17.1 \%$ & $71.4 \%$ & & & & \\
\hline \multirow[t]{2}{*}{ Turdaș-Petrești } & 0 & 0 & 0 & 47 & 2 & 0 & 1 & 50 \\
\hline & & & & $94.0 \%$ & $4.0 \%$ & & $2.0 \%$ & \\
\hline \multirow[t]{2}{*}{ Petrești } & 1 & 0 & 8 & 60 & 1 & 3 & 1 & 74 \\
\hline & $1.4 \%$ & & $10.8 \%$ & $81.1 \%$ & $1.4 \%$ & $4.1 \%$ & $1.4 \%$ & \\
\hline \multirow[t]{2}{*}{ Petrești-Coțofeni } & 1 & 0 & 3 & 16 & 2 & 0 & 0 & 22 \\
\hline & $4.5 \%$ & & $13.6 \%$ & $72.7 \%$ & $9.1 \%$ & & & \\
\hline \multirow[t]{2}{*}{ Totals } & 37 & 6 & 63 & 183 & 13 & 4 & 2 & 308 \\
\hline & $12.0 \%$ & $1.9 \%$ & $20.5 \%$ & $59.4 \%$ & $4.2 \%$ & $1.3 \%$ & $0.6 \%$ & \\
\hline
\end{tabular}


Table 5. Imported artefacts by culture group at Tărtăria site.

\begin{tabular}{|c|c|c|c|c|c|c|c|c|c|c|c|c|}
\hline Culture & Blade & $\%$ & Scraper & $\%$ & Core & $\%$ & Flake & $\%$ & Perforator & $\%$ & Total imported & Total all \\
\hline Vinča A & 10 & $58.8 \%$ & 0 & & 0 & & 7 & $41.2 \%$ & 0 & & 17 & 27 \\
\hline Vinča B & 23 & $36.5 \%$ & 5 & $7.9 \%$ & 1 & $1.6 \%$ & 33 & $52.4 \%$ & 1 & $1.6 \%$ & 63 & 88 \\
\hline Vinča B-C & 0 & & 0 & & 0 & & 3 & $100.0 \%$ & 0 & & 3 & 12 \\
\hline Vinča C / Turdaș & 5 & $50.0 \%$ & 1 & $10.0 \%$ & 0 & & 4 & $40.0 \%$ & 0 & & 10 & 35 \\
\hline Turdaș-Petrești & 0 & & 0 & & 0 & & 0 & & 0 & & 0 & 50 \\
\hline Petrești & 7 & $77.8 \%$ & 1 & $11.1 \%$ & 1 & $11.1 \%$ & 0 & & 0 & & 9 & 74 \\
\hline \multirow[t]{2}{*}{ Petrești-Coțofeni } & 3 & $75.0 \%$ & 0 & & 0 & & 1 & $25.0 \%$ & 0 & & 4 & 22 \\
\hline & 48 & $45.3 \%$ & 7 & $6.6 \%$ & 2 & $1.9 \%$ & 48 & $45.3 \%$ & 1 & $0.9 \%$ & 106 & 308 \\
\hline
\end{tabular}

Table 6. Local materials artefacts by culture group, at Tărtăria site.

\begin{tabular}{lccccccccccc|c|c}
\hline Culture & Blade & $\%$ & Scraper & $\%$ & Core & $\%$ & Flake & $\%$ & Debitage & $\%$ & Total local & Total all \\
\hline Vinča A & 3 & $30.0 \%$ & 1 & $10.0 \%$ & 1 & $10.0 \%$ & 5 & $50.0 \%$ & 0 & & 10 & 27 \\
\hline Vinča B & 10 & $40.0 \%$ & 3 & $12.0 \%$ & 2 & $8.0 \%$ & 9 & $36.0 \%$ & 1 & $4.0 \%$ & 25 & 88 \\
\hline Vinča B-C & 1 & $11.1 \%$ & 3 & $33.3 \%$ & 3 & $33.3 \%$ & 2 & $22.2 \%$ & 0 & & 9 & 12 \\
\hline Vinča C / Turdaș & 13 & $52.0 \%$ & 3 & $12.0 \%$ & 1 & $4.0 \%$ & 8 & $32.0 \%$ & 0 & & 25 & 35 \\
\hline Turdas-Petrești & 12 & $24.0 \%$ & 5 & $10.0 \%$ & 6 & $12.0 \%$ & 27 & $54.0 \%$ & 0 & & 50 & 50 \\
\hline Petrești & 26 & $40.0 \%$ & 11 & $16.9 \%$ & 7 & $10.8 \%$ & 20 & $30.8 \%$ & 1 & $1.5 \%$ & 65 & 74 \\
\hline Petrești-Coțofeni & 7 & $38.9 \%$ & 2 & $11.1 \%$ & 1 & $5.6 \%$ & 8 & $44.4 \%$ & 0 & & 18 & 22 \\
\hline & $\mathbf{7 2}$ & $\mathbf{3 5 . 6 \%}$ & $\mathbf{2 8}$ & $\mathbf{1 3 . 9 \%}$ & $\mathbf{2 1}$ & $\mathbf{1 0 . 4 \%}$ & $\mathbf{7 9}$ & $\mathbf{3 9 . 1 \%}$ & $\mathbf{2}$ & $\mathbf{1 . 0 \%}$ & $\mathbf{2 0 2}$ & $\mathbf{3 0 8}$ \\
\hline
\end{tabular}

Table 7. Obsidian artefacts by culture group, at Tărtăria site.

\begin{tabular}{|c|c|c|c|c|c|c|c|c|c|c|c|c|}
\hline Culture & Blade & $\%$ & Scraper & $\%$ & Core & $\%$ & Flake & $\%$ & Perforator & $\%$ & Total obsidian & Total all \\
\hline Vinča A & 6 & $60.0 \%$ & 0 & & 0 & & 4 & $40.0 \%$ & 0 & & 10 & 27 \\
\hline Vinča B & 13 & $38.2 \%$ & 1 & $2.9 \%$ & 1 & $2.9 \%$ & 18 & $52.9 \%$ & 1 & $2.9 \%$ & 34 & 88 \\
\hline Vinča B-C & 0 & & 0 & & 0 & & 2 & $100.0 \%$ & 0 & & 2 & 12 \\
\hline Vinča C / Turdaș & 3 & $50.0 \%$ & 0 & & 0 & & 3 & $50.0 \%$ & 0 & & 6 & 35 \\
\hline Turdaș-Petrești & 0 & & 0 & & 0 & & 0 & & 0 & & 0 & 50 \\
\hline Petrești & 6 & $75.0 \%$ & 1 & $12.5 \%$ & 1 & $12.5 \%$ & 0 & & 0 & & 8 & 74 \\
\hline \multirow[t]{2}{*}{ Petrești-Coțofeni } & 2 & $66.7 \%$ & 0 & & 0 & & 1 & $33.3 \%$ & 0 & & 3 & 22 \\
\hline & 30 & $47.6 \%$ & 2 & $3.2 \%$ & 2 & $3.2 \%$ & 28 & $44.4 \%$ & 1 & $1.6 \%$ & 63 & 308 \\
\hline
\end{tabular}


Table 8. Moldavian flint artefacts by culture group, at Tărtăria site.

\begin{tabular}{|c|c|c|c|c|c|c|c|c|c|}
\hline Culture & Blade & $\%$ & Scraper & $\%$ & Core & Flake & $\%$ & Total Moldavian & Total all \\
\hline Vinča A & 4 & $57.1 \%$ & 0 & & 0 & 3 & $42.9 \%$ & 7 & 27 \\
\hline Vinča B & 7 & $30.4 \%$ & 4 & $17.4 \%$ & 0 & 12 & $52.2 \%$ & 23 & 88 \\
\hline Vinča B-C & 0 & & 0 & & 0 & 1 & $100.0 \%$ & 1 & 12 \\
\hline Vinča C / Turdaș & 2 & $50.0 \%$ & 1 & $25.0 \%$ & 0 & 1 & $25.0 \%$ & 4 & 35 \\
\hline Turdaș-Petrești & 0 & & 0 & & 0 & 0 & & 0 & 50 \\
\hline Petrești & 1 & $100.0 \%$ & 0 & & 0 & 0 & & 1 & 74 \\
\hline \multirow[t]{2}{*}{ Petrești-Coțofeni } & 1 & $100.0 \%$ & 0 & & 0 & 0 & & 1 & 22 \\
\hline & 15 & $40.5 \%$ & 5 & $13.5 \%$ & 0 & 17 & $45.9 \%$ & 37 & 308 \\
\hline
\end{tabular}

Table 9. Balkan flint artefacts by culture group, at Tărtăria site.

\begin{tabular}{lcccccc|c|c}
\hline Culture & Blade & $\%$ & Scraper & Core & Flake & $\%$ & Total alkan & Total all \\
\hline Vinča A & 0 & & 0 & 0 & 0 & & 0 & 27 \\
\hline Vinča B & 3 & $50.0 \%$ & 0 & 0 & 3 & $50.0 \%$ & 6 & 88 \\
\hline Vinča B-C & 0 & & 0 & 0 & 0 & & 0 & 12 \\
\hline Vinča C / Turdaș & 0 & & 0 & 0 & 0 & & 0 & 35 \\
\hline Turdaș-Petrești & 0 & & 0 & 0 & 0 & & 0 & 50 \\
\hline Petrești & 0 & & 0 & 0 & 0 & & 0 & 74 \\
\hline Petrești-Coțofeni & 0 & & 0 & 0 & 0 & & 0 & 22 \\
\hline & $\mathbf{3}$ & $\mathbf{5 0 . 0 \%}$ & $\mathbf{0}$ & $\mathbf{0}$ & $\mathbf{3}$ & $\mathbf{5 0 . 0 \%}$ & $\mathbf{6}$ & $\mathbf{3 0 8}$ \\
\hline
\end{tabular}




\section{Conclusions, significance, opinions}

\subsection{General movement of materials, trade, and cultures}

The fact that obsidian and Miorcani Moldavian flint were found at the site demonstrates the existence of long distance imported materials, in this case from outside of the territory of the people who occupied the settlement. It should be noted that similar tools were produced from local and imported materials. The types and general proportions of stone tool types remain the same over time. People did not necessarily need the imported materials. The local materials were sufficient.

Import in the proportions observed indicates that the people of the settlement knew about various non-local, high quality materials available in adjacent regions. These materials would have been well known to most people and a demand for them existed. If people were not travelling to the sources themselves to get materials, then it is likely that there were established long distance trade routes in existence by the early Neolithic and maintained throughout this period. More importantly, these trade routes were intercultural. This is an important observation because it has generally been believed that long distance trade did not appear until the end of the Chalcolithic or beginning of the Bronze Age. Along with the proportions of imported materials, the continuation of these trends over time suggests regular contact and interaction with neighbouring cultures. As economics is an aspect of culture, if these cultures were interacting economically then this type of discovery requires researchers to reconsider the current definitions of the cultures of that time period and what separates them.

Balkan flint was used less than Miorcani Moldavian flint, even though the latter was located within the territory of another culture and the former was available (and highly used) within the Vinča culture territory to the south of the Carpathians. The larger proportion of imported material from the North (including obsidian) suggests stronger trade or social connection with the cultures to the North (outside of their own cultural territories.) As with the results from other sites, this indicates that areas of similar artistic style (often the main characteristic used to define culture areas) do not in fact match areas of economic interaction. This further supports the need for a redefining of cultures and cultural territories.

As the site was located on the bank of a major waterway, it is very likely that the people living there had relatively easy access to and contact with other settlements, thereby facilitating trade of raw materials and finished products. What the residents of the site traded in exchange for lithic materials remains unknown. Some researchers (for example, Banffy 2013; Cavruc 2005; 2008; Cavruc \& Dumitroaia 2006; Cavruc \& Harding 2012; Cavruc \& Harding 2011) have proposed that salt may have been traded - a relatively abundant material in some areas. It is also possible that such settlements along the banks of major rivers may have served as a sort of market place where traders met to exchange goods.

\subsection{Changes over time}

The artefacts indicate that there was both local procurement and long distance procurement but proportions of local and imported materials changed over time. It would seem that the amount of artefacts made from local materials increased although imported long distance materials were still coming from the same areas - only in smaller quantities. This decrease in imported materials seems to have occurred over time.

The earlier artefacts indicate that the people living at the site tended to have more preference for imported materials, particularly from the north. The most commonly imported material was obsidian, followed closely by Miorcani Moldavian flint (Figure 7). Local materials were commonly used, representing about two thirds of the artefacts. Balkan flint is 
common but low in quantity compared to other materials. Late Neolithic and Chalcolithic sites of the area used imported materials (especially obsidian) but, in time local materials became more and more predominant.

It is hard to know for sure why there is a change at Tărtăria in the Chalcolithic to more local materials. It may be simply a cultural preference and more reliance on self-sufficiency during this period. The decrease in the import of lithic materials may have been caused by a decrease in communication with distant communities. It may also have been due to a drop in the perceived value of imported lithic materials - perhaps due to the introduction into the economy of a new exotic material - copper. It may therefore have been simply a transfer of prestige from one material to another.

\subsection{Potential connection with Răcătău-Piatra Tomii}

One of the most interesting observations regarding the lithic assemblage from Tărtăria is how it differs from the others in the area. Among the lithic artefacts, there is a very low amount of local materials other than chert. Likewise, there is a higher proportion of local lithic materials in general compared to imported materials.

Almost all of the local material at the site is chert. At other Middle Mureș Valley sites looked at in related studies (for example, Crandell 2008; 2009a; 2011; 2012b; Crandell \& Popa 2015), there was more of a mix of jasper and chert. Although sites like Limba and Lumea Nouă are further from the main sources of jasper, they still contain higher percentages of it than Tărtăria does.

These differences may be connected with possible chert quarrying at Răcătău-Piatra Tomii. The two sites appear to have been contemporary with each other. It may have been that they were in some way connected regarding the trade in the area or may have been occupied by the same people. If so, then since they were close to a source and had an abundance of their own materials, it may have been counter-productive (from a functional point of view) to trade for jasper or other materials from neighbouring sites along the Mureș Valley. Another possibility is that the close proximity of Tărtăria to an exporting site (Răcătău) meant that they could acquire this particular raw material more cheaply or readily than the materials from other locations in the Mureș Valley.

\section{Acknowledgements}

The majority of the artefacts (from the 1989 excavation) came from the collection of the Institute of Systemic Archaeology ("1 Decembrie 1918” University of Alba Iulia, Romania). Access to the artefacts and permission to study them was granted by the late Dr. Iuliu Paul, at that time the director of the institute and scientific director of the Tărtăria site. Information regarding their cultural origins and stratigraphic context was also provided by Paul (head researcher of the site in 1989 and scientific director of the site from 1996 to 2001). Dr. Zoia Maxim and Luminița Sasaran provided access to the artefacts from Nicolae Vlassa's excavation in 1961 and Kurt Horedt's excavations in 1942 and 1943. The raw material samples were taken from the Romanian Lithotheque Project collection housed at BabesBolyai University. Petrographic thin sectioning and analyses were carried out at the Geology Department of Babeş-Bolyai University. This work was supported by funds from the Romanian Ministry of Education and Research projects PNII-ID 2241/2008 (CNCSUEFISCDI) and PN-II-ID-PCE-2011-3-0881. 


\section{References}

Alba, C.N., Gheorghiu, C. \& Popescu, I. 1960, Depozitele sedimentare de la Rădăuți-Prut. Comunicări de Geologie-Geografie, 1(1957-1959): 9-23. (in Romanian) ("Sedimentary deposits of Rădăuți-Prut")

Banffy, E. 2013, Tracing 6th-5th millennium BC salt exploitation in the Carpathian Basin. In: Explorations in Salt Archaeology in the Carpathian Basin. Fieldwork in central and eastern Europe, 2002-2012 (Harding, A.F. \& Kavruk, V., Eds.), Budapest, Archaeolingua: p. 101-107.

Barfield, L. 2004, Lithics, culture and ethnic identity. Lithics. Journal of the Lithic Studies Society, 25: 65-77.

Biagi, P., de Francesco, A.M. \& Bocci, M. 2007a, New data on the archaeological obsidian from the Middle-Late Neolithic and the Chalcolithic sites of the Banat and Transylvania (Romania). In: The Lengyel, Polgár and related cultures in the Middle/Late Neolithic in Central Europe (Kozłowski, J.K. \& Raczky, P., Eds.), Polska Akademia Umiejętności, Cracow: p. 309-326.

Biagi, P., Gratuze, B. \& Bouchetta, S. 2007b, New data on the archaeological obsidians from the Banat and Transylvania (Romania). In: A Short Walk through the Balkans: the First Farmers of the Carpathian Basin and Adjacent Regions (Spataro, M. \& Biagi, P., Eds.), Quaderno Vol. 12, Società per la preistoria e protostoria della regione Friuli-Venezia Giulia, Trieste: p. 129-148.

Biagi, P. \& Starnini, E. 2010, A source in Bulgaria for Early Neolithic 'Balkan flint'. Antiquity+, 84(325). URL: http://www.antiquity.ac.uk/projgall/biagi325/

Biagi, P. \& Starnini, E. 2011, First discovery of Balkan flint sources and workshops along the course of the Danube river in Bulgaria. In: Panonski prapovijesni osviti: Zbornik radova posvećenih Korneliji Minichreiter uz 65. obljetnicu života. (Dizdar, M., Ed.), Institu za Arheologiju, Zagreb: p. 69-81.

Biagi, P. \& Voytek, B.A. 2006, Excavations at Pestera Ungureasca (Caprelor) (Cheile Turzii, Petresti de Jos, Transylvania) 2003-2004: A preliminary report on the chipped stone assemblages from the Chalcolithic Toarte Pastilate (Bodrogkeresztur) layers. Analele Banatului, S.N., Arheologie - Istorie, 14(1): 177-202.

Biró, K.T. 2006, Carpathian obsidians: Myth and reality. In: Proceedings of the 34th International Symposium on Archaeometry (Pérez-Arantegui, J., Ed.), Institución "Fernando el Católico", Zaragoza: p. 267-277.

Boghian, D.D. 2009, Din nou despre unele surse de materie primă pentru confecționarea utilajului litic al comunităților complexului cultural Precucuteni-Cucuteni. Suceava Anuarul Complexului Muzeal Bucovina, 34-36: 117-146. (in Romanian) ("Again about several sources of raw material for producing lithic tools of the communities of the Precucuteni-Cucuteni cultural complex")

Bonsall, C., Gurova, M., Hayward, C., Nachev, C.I. \& Pearce, N.J.G. 2010, Characterization of 'Balkan flint' artefacts from Bulgaria and the Iron Gates using LA-ICP-MS and ЕРМА. Интердисииплинарни изследвания (Interdisciplinary Studies), 22-23: 9-18.

Borcoş, M., Berbeleac, I., Bordea, S., Bordea, J., Mantea, G. \& Boștinescu, S. 1981, Geological Map of Romania, scale 1:50000, 74c Zlatna Sheet. Romanian Institute of Geology and Geophysics, Bucharest. (in Romanian) 
Brana, V. 1967, Zacaminte nemetalifere din Romania. Editura Tehnică, Bucharest, 470 p. (in Romanian) ("Non-metalliferous ore deposits of Romania")

Cavruc, V. 2005, Some Eneolithic and Bronze Age funeral evidence on the salt exchange routs in Southeast Transylvania. Musaios, 10: 325-351.

Cavruc, V. 2008, The present stage of the researches regarding prehistoric salt production in the Carpatho-Danubian region. Angustia, 12: 79-90.

Cavruc, V. \& Dumitroaia, G. 2006, Vestigii arheologice privind exploatarea sării pe teritoriul României în perioada neo-eneolitică. In: Sarea, Timpul și Omul (Cavruc, V. \& Chiricescu, A., Eds.), Editura Angustia, Sfîntu Gheorghe: p. 37-40. (in Romanian) ("Archaeological remains relating to the exploitation of salt in the territory of Romania in the Neo-Eneolithic period")

Cavruc, V. \& Harding, A. 2012, Prehistoric production and exchange of salt in the Carpathian-Danube Region. In: Salt and Gold: The Role of Salt in Prehistoric Europe (Nikolov \& Bacvarov, Eds.), Provadia-Veliko, Tarnovo: p. 172-200.

Cavruc, V. \& Harding, A.F. 2011, New archaeological researches concerning saltworking in Transylvania. Preliminary report. In: Archaeology and anthropology of salt: A diachronic approach. Proceedings of the International Colloquium, 1-5 October 2008 Al. I. Cuza University (Iaşi, Romania) (Alexianu, M., Weller, O. \& Curcă, R.-G., Eds.), BAR International Series Vol. S2198, Archaeopress, Oxford: p. 111-122.

Chelărescu, A., Nichita, O. \& Mihul, A. 1961, Zăcămîntul de nisip alb de la MiorcaniHudești, sursa de materie primă pentru sticlă fină. Studii și Cercetari Stiintifice (Fizica si stiinte tehnice), 12(1): 67-77. (in Romanian) ("White sand ore of Miorcani-Hudești, source of raw material for fine glass")

Chiriac, M. 1957, Contributions a l'etude de la faune des échinides Crétacés de la Dobrogea du Sud. Revue de Geologie et de Geographie, Academie de la Republique Populaire Roumaine, 1: 61-95, pl. 1-13. (in French) ("Contributions to the faunal study of Cretaceous echinoids from Southern Dobrogea")

Chiriac, M. 1964, Asupra unor iviri de turonian la E de Medgidia. Studii și Cercetari de Geologie, Geofizica, Geografie, Sectia Geologie, 9(2): 329-339. (in Romanian) ("Regarding the emergence of the Turonian to the E of Medgidia")

Chiriac, M. 1981, Amoniții Cretacici din Dobrogea de Sud. Studiu biostratigrafic. Academiei Republicii Socialiste Romania, Bucharest, 143 p. (in Romanian) ("Cretaceous Ammonites in south Dobrogea. Biostratigraphic study")

Chiriac, M., Bărbulescu, A., Neagu, T. \& Dragastan, O. 1977, La Dobrogea centrale et du sud pendant le Jurassique et le Crétacé. Revue Roumaine de Géologie, Géophysique et Géographie - Série de Géologie, 21: 145-153. (in French) ("Central and southern Dobrogea during the Jurassic and Cretaceous")

Chirica, V., Borziac, I.A. \& Chetraru, N.A. 1996, Gisements du paléolithique supérieur ancien entre le Dniestr et la Tissa. Bibliotheca archaeologica Iassiensis Vol. 5. Editura Helios, Iaşi, 323 p. (in French) ("Deposits of the Upper Palaeolithic between the Dniester and Tissa")

Ciocârdel, R. 1953, Geologia regiunii Andreiașul (Putna). Contribuțiuni la cunoașterea geologiei Dobrogei Centrale. Dări de Seamă ale Ședințelor. Comitetul Geologic, 37(1949-1950): 153-161. (in Romanian) ("Geology of the Andreiașul (Putna) region. Contributions to the understanding of the geology of Central Dobrogea") 
Ciocârdel, R. \& Popovici, M. 1954, Date privind sursele de apă de la Caragea Dermen (regiunea Constanța). Dări de Seamă ale Ședințelor. Comitetul Geologic, 38(19501951): 321-324. (in Romanian) ("Data regarding the sources of water of Caragea Dermen (Constanța region)")

Comșa, E. 1975, Le silex de type 'Balkanique'. Peuce, 4: 5-19. (in French) ("Balkanic type flint")

Comșa, E. 1976, Les matières premières en usage chez les hommes Néolithiques de l'actuel territoire Roumain. Acta Archaeologica Carpathica, 16: 239-249. (in French) ("The raw materials in use among the Neolithic people of the present-day Romanian territory")

Comșa, E. 1982, Neoliticul din România. Știința pentru toți. Editura Științifică și Enciclopedică, Bucharest, 112 p. (in Romanian) ("The Neolithic in Romania")

Constantina, C. 2008, Studiul complexului vulcanoclastic paleocen din regiunea SârbiGurasada-Burjuc (Valea Mureşului), cu privire specială asupra mineralelor cu valoare gemologică. Ph.D. thesis at the Geology Department, Babeș-Bolyai University, ClujNapoca, 135 p. (in Romanian) ("The study of the Paleocene volcanoclastic complex from the Sârbi-Gurasada-Burjuc region (Mureș Valley), concerning the minerals with gemological value")

Constantinescu, B., Bugoi, R. \& Sziki, G. 2002, Obsidian provenance studies of Transylvania's Neolithic tools using PIXE, micro-PIXE and XRF. Nuclear Instruments and Methods in Physics Research Section B: Beam Interactions with Materials and Atoms, 189(1-4): 373-377. doi:10.1016/s0168-583x(01)01092-8

Crandell, O.N. 2005, Macroscopic analysis and characterisation of chert for provenance purposes. Sargetia, Acta Musei Devensis, 33: 137-153.

Crandell, O.N. 2006, Macroscopic and microscopic analysis of chert: A proposal for standardisation of methodology and terminology. Buletinul Cercurilor Științifice Studențești, 12: 7-30.

Crandell, O.N. 2008, Regarding the procurement of lithic materials at the Neolithic site at Limba (Alba county, Romania): Sources of local and imported materials. In:

Geoarchaeology and Archaeomineralogy. Proceedings of the International Conference, 29-30 October 2008 Sofia. (Kostov, R.I., Gaydarska, B.I. \& Gurova, M., Eds.), Publishing House "St. Ivan Rilski”, Sofia: p. 36-45.

URL: http://mgu.bg/geoarchmin/naterials/06Crandell.pdf

Crandell, O.N. (2009a), The provenance of Neolithic and Chalcolithic stone artefacts from the Lumea Noua site, Alba Iulia, Romania. unpublished manuscript. 30 p.

Crandell, O.N. 2009b, Romanian Lithotheque Project: Knappable stone resources in the Mureș Valley, Romania. Studia UBB, Geologia, Special Issue, MAEGS - 16: 79-80. URL: http://www.studia.ubbcluj.ro/arhiva/abstract_en.php?editie=GEOLOGIA\&nr=Sp ecial\%20Issue\&an=2009\&id_art=7388

Crandell, O.N. 2011, Evaluation of PGAA data for provenance of lithic artifacts. Studia UBB, Geologia, 57(1): 3-11. doi:10.5038/1937-8602.57.1.1

Crandell, O.N. 2012a, Lithic sources available to prehistoric populations in the Banat region, Romania. In: Interdisciplinary Research in Archaeology. Proceedings of the First Arheoinvest Congress, 10-11 June 2011, Iași, Romania (Cotiugă, V. \& Caliniuc, S., Eds.), B.A.R. International Series Vol. 2433, Archaeopress, Oxford: p. 69-78. 
Crandell, O.N. 2012b, Petrographic analysis of lithic artefacts from Limba (Romania) to confirm Neolithic trade patterns. Acta Mineralogica-Petrographica, Szeged, 7: 31.

Crandell, O.N. 2012c, Petrographic evidence of intercultural trade during the Chalcolithic; Examples from Neamț county, Romania. In: Depresiunea Neamţ. Contribuţii arheologice (Diaconu, V., Ed.), Bibliotheca Memoriae Antiquitatis Vol. 28, Editura Constantin Matasă, Piatra Neamţ: p. 147-158.

Crandell, O.N. 2013, The provenance of Neolithic and Chalcolithic stone tools from sites in Teleorman county, Romania. Buletinul Muzeului Judeţean Teleorman, Seria Arheologie, 5: 125-142.

URL: http://www.muzeulteleorman.ro/files/03_BMJT5_Crandell.pdf

Crandell, O.N. 2014a, Knappable lithic resources of North-Western Romania: A mineralogical study. Journal of Lithic Studies, 1(1): 73-84. doi:10.2218/jls.v1i1.824

Crandell, O.N. 2014b, Knappable materials in the Criș Valley, Romania. Journal of Lithic Studies, 1(2): 47-62. doi:10.2218/jls.v1i2.1101

Crandell, O.N. in press, Revisiting the question of Balkan Flint in southern Romania; Some observations on artefacts and geological sources. In: Balkan Flint in SE European Prehistory (Bonsall, C., Ed.), British Archaeological Reports (BAR) International series, Archaeopress, Oxford: 8 p.

Crandell, O.N. \& Mărcuţi, F. in press, Provenance of Neolithic stone artefacts from the Banat Region, Romania. In: Interdisciplinary research in archaeology. Proceedings of the Second Arheoinvest Congress, Iaşi, Romania (Cotiugă, V., Ed.), B.A.R. International Series, Archaeopress, Oxford: 18 p.

Crandell, O.N., Niţă, L. \& Anghelinu, M. 2013, Long-distance imported lithic raw materials at the Upper Palaeolithic sites of the Bistriţa Valley (Carpathian Mts.), Eastern Romania. Lithics, 34: 30-42.

Crandell, O.N. \& Popa, C.I. 2015, The chert quarrying and processing industry at the Piatra Tomii site, Romania. Journal of Lithic Studies, 2(1): 45-63. doi:10.2218/jls.v2i1.1154

Crandell, O.N. \& Vornicu, D.-M. 2015, Aspects of long distance trade by the Precucuteni culture. Transylvanian Review, 24(2): 85-108.

Gandrabura, E.I. 1981, Studiul mineralogic, petrografic și geochimic al eruptivului mezozoic din Munții Trascău. Anuarul Institutului de Geologie şi Geofizică, 58: 5-121. (in Romanian) ("Mineralogical, petrographical and geochemical study of the Mesozoic eruptive rocks in the Trascău Mountains")

Gherasi, N., Mureșan, M., Muresan, G., Kräutner, H., Kräutner, F., Lupu, M., Marinescu, F., Savu, H. \& Drăgulescu, A.A. 1965, Geological Map of Romania, scale 1:200,000, 25 Deva Sheet. Romanian Geological Institute, Bucharest. (in Romanian)

Ghiurcă, V. 1997, Gemologia arheologică și resursele gemologice actuale din partea de nord a Munților Trascău. Acta Musei Napocensis, Preistorie-Istorie veche-Arheologie, 34(1): 829-835. (in Romanian) ("Archaeological gemology and modern gemological resources from the northern part of the Trascău Mountains")

Ghiurcă, V. 2000, Aria de apariție a mineralelor silicioase de pe Culoarul Mureșului (HD). Acta (Siculica), 2000(1): 21-38. (in Romanian) ("Area of occurrence of siliceous minerals along the Mureș Corridor (HD)") 
Giușcă, D., Cioflica, G. \& Savu, H. 1966, Caracterizarea petrologică a provinciei banatitice. Anuarul Comitetului de Stat al Geologiei, 35: 13-45. (in Romanian) ("The petrological features of the Banatitic Province")

Gurova, M. 2008, Towards an understanding of Early Neolithic populations: a flint perspective from Bulgaria. Documenta Praehistorica, 35: 111-129. doi:10.4312/dp.35.8

Horedt, K. 1949, Săpături privitoare la epoca neo-eneolitică. Apulum, 3: 44-69. (in Romanian) ("Excavations regarding the Neo-Eneolithic")

Iancu, G.O. \& Iancu, G. 2009, Mineral chemistry of some agates from Gurasada (Mures Valley, Romania). Studia UBB Geologia, 54(1): 37-41. doi:10.5038/1937-8602.54.1.8

Ianovici, V., Giușcă, D., Mutihac, V., Mirăută, O. \& Chiriac, M. 1961, Privire generală asupra geologiei Dobrogei. Ghidul excursiilor, D. Asociația Geologică CarpatoBalcanică, Bucharest, 89 p. (in Romanian) ("General overview of the geology of Dobrogea")

Ionesi, L. 1988, Geologia Romaniei. unitati de platforma si orogenul nord dobrogean. Universitatea Al.I. Cuza, Iași, 253 p. (in Romanian) ("Geology of Romania. Northern Dobrogean platform and orogen units")

Ionesi, L. \& Costea, C. 1993, Exoscopia granulelor de cuarț din nisipurile badeniene de AlbaMiorcani (Platforma Moldovenescă). Analele Științifice ale Universității "Al.I.Cuza", 38-39(2): 273-277. (in Romanian) ("Exoscopy of quartz grains from Badenian sands from Alba-Miocani (Moldavian Platform)")

Jolkičev, N. 2007, The Cretaceous/Paleogene boundary in the Eastern Fore Balkan; (Luda Kamchya Defile - locality of Chudnite Steni). Review of the Bulgarian Geological Society, 68(1-3): 41-45.

Kasztovszky, Z.S. \& Biró, K.T. 2006, Fingerprinting Carpathian obsidian by PGAA: first results on geological and archaeological sources. In: Proceedings of the 34th International Symposium on Archaeometry (Pérez-Arantegui, J., Ed.), Institución "Fernando el Católico", Zaragoza: p. 301-308.

Lupu, M., Borcoş, M., Dimian, M., Lupu, D. \& Dimitrescu, R. 1966, Geological Map of Romania, scale 1:200,000, 18 Turda Sheet. Romanian Geological Institute, Bucharest. (in Romanian)

Lupu, M., Marinescu, F., Roșu, E., Nicolae, I., Mureșan, M. \& Popescu, A. 1991, Geological Map of Romania, scale 1:50000, 88b Lapugiu Costei Sheet. Romanian Institute of Geology and Geophysics, Bucharest. (in Romanian)

Lupu, M., Pelty, S., Boștinescu, S., Roșu, E., Kräutner, H.G., Horvath, A., Mureșan, M., Mureșan, G., Bandrabur, T., Popescu, A. \& Nicolae, I. 1986, Geological Map of Romania, scale 1:50000, 89a Gurasada Sheet. Romanian Institute of Geology and Geophysics, Bucharest. (in Romanian)

Macovei, G. 1958, Geologie stratigrafică cu privire specială la teritoriul României. Editura Tehnică, Bucharest, 567 p. (in Romanian) ("Stratigraphic geology with special look at the territory of Romania")

Macovei, G. \& Atanasiu, I. 1934, L'évolution géologique de la Roumainie. Crétacé. Anuarul Institutului Geologic din României, 16(1931): 63-280. (in Romanian) ("The geological evolution of Romania. Cretaceous") 
Moga, V. \& Ciugudean, H. 1995, Repertoriul arheologic al județului Alba. Bibliotheca Musei Apulensis Vol. 2. Muzeul Naţional al Unirii Alba Iulia, Alba Iulia, 172 p. (in Romanian) ("The archaeological repertory of Alba district")

Mutihac, V. \& Ionesi, L. 1974, Geologia României. Editura Tehnică, Bucharest, 646 p. (in Romanian) ("The Geology of Romania")

Nachev, C.I. 2009, Flint raw materials in Bulgaria. In: The First Neolithic Sites in Central/South-East European Transect Volume I: Early Neolithic Sites on the Territory of Bulgaria (Gatsov, I. \& Boyadzhiev, Y., Eds.), BAR Vol. S2048, Archaeopress, Oxford: p. 57-58.

Nicolae, I. \& Saccani, E. 2003, Petrology and geochemistry of the Late Jurassic calc-alkaline series associated to Middle Jurassic ophiolites in the South Apuseni Mountains (Romania). Schweizerische Mineralogische und Petrographische Mitteilungen, 83(1): 81-96. URL: http://www.geo.edu.ro/sgr/mod/downloads/PDF/Nicolae-SSMP-2003-8381.pdf

Oddone, M., Márton, P., Bigazzi, G. \& Biró, K. 1999, Chemical characterisations of Carpathian obsidian sources by instrumental and epithermal neutron activation analysis. Journal of Radioanalytical and Nuclear Chemistry, 240(1): 147-153. doi:10.1007/bf02349147

Orosz, E. 1908, Ujabban fölfedezett erdélyi õstelepek. Erdélyi Múzeum, 25(4): 256-259. (in Hungarian) ("More recently discovered ancient settlements in Transylvania") URL: http://hdl.handle.net/10598/4225

Paul, I.A. 2011, Enigma tăblițelor de la Tărtăria - Schiță preliminară. Conferințele Bibliotecii ASTRA, 130: 9-73. (in Romanian) ("The enigma of the tablets from Tărtăria Preliminary outline"); URL: http://www.bjastrasibiu.ro/conferinte/130-iuliu.paul.pdf

Połtowicz-Bobak, M. 2005, The Magdalenian period in Poland and neighbouring areas. Archaeologia Baltica, 7: 21-28.

Pop, D., Constantina, C., Tătar, D. \& Kiefer, W. 2004, Raman spectroscopy on gem-quality microcrystalline and amorphous silica varieties from Romania. Studia UBB, Geologia, 49(1): 41-52. URL: http://scholarcommons.usf.edu/geologia/vol49/iss1/art4

Radu, D. 1967, Muzeul Regional Alba Iulia; Scurtă privire istorică. Apulum, 6: 557-589. (in Romanian) ("Alba Iulia Regional Museum; brief historical overview")

Rosania, C.N., Boulanger, M.T., Biró, K.T., Ryzhov, S., Trnka, G. \& Glascock, M.D. 2008, Revisiting Carpathian obsidian. Antiquity, 82(318).

URL: http://antiquity.ac.uk/projgall/rosania/index.html

Ryzhov, S., Stepanchuk, V. \& Sapozhnikov, I. 2005, Raw material provenance in the Palaeolithic of Ukraine: state of problem, current approaches and first results.

Archeometriai Mühely, 2005(4): 17-25. URL: http://www.ace.hu/am/2005_4/AM-20054-RYZ.pdf

Sălăgean, M., Pantelica, A., Daraban, L. \& Fiat, T. 1988, Provenance studies of obsidian from the Neolithic settlement of Partza in South-Western Romania. Chapter 164. In: First Romanian Conference on the Application of Physics Methods in Archaeology, ClujNapoca, 5-6 November 1987 Vol. 1 (Frangopol, P.T. \& Morariu, V.V., Eds.), Central Institute of Physics (Romania), Bucharest: p. 73-86. 
Saulea, E., Popescu, I. \& Bratu, E. 1966, Geological Map of Romania, scale 1:200,000, 1 Darabani Sheet. Romanian Geological Institute, Bucharest. (in Romanian)

Savu, H. 1990, Remarks on the Mesozoic magmatic activity in the Trascău Mountains (Mureş Zone). Revue Roumaine de Géologie, Géophysique et Géographie - Série de Géologie, 34: 13-24.

Simionescu, I.T. 1897, Creta Superioară și calcarele cu Lithothamnium pe malul Prutului. Archiva Societatii de Știinte Iași, 8. (in Romanian) ("Upper chalk and limestone with Lithothamnium on the bank of the Prut")

Sytnyk, O., Koulakovskaya, L., Usik, V., Geneste, J.-M., Meignen, L., Bohuts’ky, A. \& Haesaerts, P. 2007, МолодовеV. Дослідження мустьєрських поселень у 1998-1999 роках. In: Materials and studies on archeology of Sub-Carpathian and Volhynian area. (Матеріали і дослідження з археологї Прикарпаття і Волині) Vol. 11 (Isaievych, I., Baran, V., Matskevyj, L. \& Sytnyk, O., Eds.), Ivan Krypiakevych Institute of Ukrainian Studies of the National Academy of Sciences of Ukraine, Lviv: p. 136-179. (in Ukrainian) ("Molodova-V. Research on Mousterian sites in 1998-1999")

Szakmány, G., Starnini, E., Horváth, F. \& Bradák, B. 2011, Investigating trade and exchange patterns in prehistory: Preliminary results of the archaeometric analyses of stone artefacts from Tell Gorzsa (South-East Hungary). In: Proceedings of the 37th International Symposium on Archaeometry, 13th - 16th May 2008, Siena, Italy (Turbanti-Memmi, I., Ed.), Springer, Heidelberg: p. 311-319. doi:10.1007/978-3-64214678-7_45

Văscăuțanu, T. 1923, Asupra cretaceului superior din Nordul Basarabiei. Analele Academiei Române, Memoriile Secțiunii Științifice (Seria 3), 1: 287-299. (in Romanian) ("Regarding the Upper Cretaceous from the north of Basarabia")

Văscăuțanu, T. 1925, Asupra formațiunilor mediterane din nordul Basarabiei. Analele Academiei României, Memoriile Secțiunii Științifice (Seria 3), 3(Mem. 6): 239-256. (in Romanian) ("Regarding the mediterranean formations from the north of Basarabia")

Vass, D. \& Balogh, K. 1987, The periods of main and late Alpine molasses. Zeitschrift der. Geologische Wissenschaften (Berlin), 17: 849-858.

Vlassa, N. 1976, Neoliticul Transilvaniei: studii, articole, note. Bibliotheca Musei Napocensis Vol. 3. Comitetul pentru Cultură și Educație Socialistă, Cluj-Napoca, 264 p. (in Romanian) ("The Neolithic of Transylvania: studies, articles, notes") 